\title{
Estimating shear wave velocity of soil using standard penetration test (SPT) blow counts in Mashhad city
}

\author{
Omolbanin Ataee ${ }^{1, *}$, Naser Hafezi Moghaddas ${ }^{2}$ and Gholam Reza Lashkaripour ${ }^{2}$ \\ ${ }^{1}$ University of Mazandaran, Babolsar, Mazandaran, Iran. \\ ${ }^{2}$ Faculty of Geology, Ferdowsi University of Mashhad, Mashhad, Iran. \\ *Corresponding author.e-mail: om.ataee@um.ac.ir
}

MS received 31 March 2016; revised 4 May 2018; accepted 14 June 2018; published online 11 March 2019

This study investigates the correlation between shear wave velocity $\left(V_{\mathrm{S}}\right)$ and standard penetration test blow counts (SPT- $N$ value) in all soil types, gravelly soil, sandy soil and clayey soil for Mashhad city in the north eastern region of Iran. The $V_{\mathrm{S}}$ data used were measured through downhole method in 84 construction projects (in 88 boreholes). From among collected data, 424 pairs of $V_{\mathrm{S}} \mathrm{SPT}$ recorded in one depth were used for regression analysis. The obtained results showed that the $N$-value had a critical role in estimating $V_{\mathrm{S}}$ and soil type was less effective in this regard. These findings are in line with the findings of the previous studies. Regression equations obtained in this study were compared with correlations from previous studies. There was a relative similarity between the previously published and the new regression equations for Iranian soils. Although almost all correlations follow a similar trend, there are significant differences between new equations and correlations reported for other countries. The regression coefficients of the new equations show the acceptable capability of the suggested correlations in estimating $V_{\mathrm{S}}$ through SPT- $N$ value. Therefore, these equations can be used to estimate $V_{\mathrm{S}}$ for the soils of the current study area and for other similar areas. Moreover, $V_{\mathrm{S} 30}$ was used for site classification of the study area as per National Earthquake Hazard Reduction Program (NEHRP) guidelines and it was shown that a major portion of the city comes under site class $\mathrm{C}$ and other locations are categorised as site class D.

Keywords. Shear wave velocity $\left(V_{\mathrm{S}}\right)$; standard penetration test blow counts (SPT- $N$ value); regression analysis; Mashhad city; Iran.

\section{Introduction}

Shear wave velocity $\left(V_{\mathrm{S}}\right)$ is a critical parameter for evaluating the dynamic characteristics of soil and analysing the seismic response of the site. According to the National Earthquake Hazard Reduction Program (NEHRP) provision (BSSC 1994), the New 1997 Uniform Building Code, and the Iranian Code of Practice for Seismic Resistance Design of Buildings (Standard No. 2800), the average $V_{\mathrm{S}}$ of the top $30 \mathrm{~m}$ of soil profile, known as $V_{\mathrm{S} 30}$, is used for classifying sites into different classes. Then, the site classifications are used in determining seismic coefficients for earthquake-resistant designs. Designers expect similar responses for the sites which are in the same class against the same earthquakes (Brown et al. 2000; Martin and Diehl 2004; Sil and Sitharam 2013). However, the determination of $V_{\mathrm{S}}$ using field experiments is preferable, but determining $V_{\mathrm{S}}$ in the field is not often economically possible. Specially, in urban areas, due to space limitations, high level of noise, lack of 
educated personnel and cost considerations, soil investigation companies avoid using this test. To overcome this problem, researchers throughout the world have attempted to measure $V_{\mathrm{S}}$ through indirect methods. In this regard, many empirical correlations were created between $V_{\mathrm{S}}$ and in-situ static tests, including standard penetration test (SPT) and cone penetration test $(\mathrm{CPT})$ which are used mostly for geotechnical studies of sites (Chatterjee and Choudhury 2013). Though there are many empirical relationships available between $V_{\mathrm{S}}$ and SPT blow counts, these relationships are for one specific area and cannot be applied to all regions.

This study attempts to investigate the relationship between $V_{\mathrm{S}}$ and the uncorrected and corrected SPT blow counts for all soil types of Mashhad city as well as for gravelly soil, sandy soil and clayey soil. Finally, using statistical methods the empirical equations for directly estimating the $V_{\mathrm{S}}$ value from the SPT- $N$ value for each of the above four groups will be suggested. At the end, the obtained formulas will be compared with the previous equations suggested by different researchers. Mashhad city has been considered as the site for this study and the $V_{\mathrm{S}}$ was measured through downhole method in 88 boreholes.

\subsection{Empirical correlations between SPT-N and $V_{\mathrm{S}}$ in previous studies}

A large number of studies can be found showing the relationship between $V_{\mathrm{S}}$ and soil geotechnical parameters such as standard penetration resistance in specific areas. Some of these studies, considering the soil type (gravel, sand, silt or clay) and some other studies considering the depth, fine content in soil, corrected or uncorrected standard penetration resistance or the geological age have investigated these relationships. Hardin and Richart (1963) conducted one of the earliest comprehensive experimental investigations on effective parameters on $V_{\mathrm{S}}$ in soils. Ohsaki and Iwasaki (1973) did a simple statistical analysis on more than 200 groups of data collected from seismic explorations (mostly through downhole method) across Japan and finally introduced an equation relating the shear modulus and $N$ value for all soil types based on data collected.

Other researchers such as Yoshimura and Imai (1970), Ohsaki and Iwasaki (1973), Imai (1977) and Ohta and Goto (1978) studied the relationship between $V_{\mathrm{S}}$ and $N$ value in various cities of Japan. They investigated the impact of soil type and geological age on these relationships. Other empirical relationships between $V_{\mathrm{S}}$ and $N$ value were suggested by Seed and Idriss (1981), Jinan (1987), Lee (1990), Pitilakis et al. (1992), Athanasopoulos (1995) and Kiku et al. (2001). Imai and Yoshimura (1975) studied the relationship between seismic velocities and a number of index properties of 192 soil samples and developed empirical relationships for all soil types. Sykora and Stokoe (1983) showed that geological age and soil type are not predictors of $V_{\mathrm{S}}$, while the $N$ value is very important. Iyisan (1996) studied the impact of soil type on the relationships between $N$ value and $V_{\mathrm{S}}$, using the data collected from an earthquake prone area in the eastern part of Turkey. Analysis of data showed the developed relationships for all types of soil, sand and clay, (with the exception of gravel) nearly gave similar $V_{\mathrm{S}}$ values. The researcher finally developed some relationships for determining $V_{\mathrm{S}}$ as a function of soil type, grain size, depth and overburden pressure.

Baziar et al. (1998) calculated the relationship between $V_{\mathrm{S}}$ and $N$ value for soils in Iran. In this study, 145 data pairs collected from eight different sites in Iran were used to develop the relationships. Jafari et al. (2002) calculated the statistical relationships between SPT and $V_{\mathrm{S}}$ for clayey soil, silty soil and fine-grained soil in Tehran city. Hasancebi and Ulusay (2007) developed new statistical correlations between $V_{\mathrm{S}}$ calculated through seismic refraction method and the corrected and uncorrected $N$ value. They used 97 data pairs collected from an area in the northwest of Turkey and developed empirical relationships for sand, clay and all soil types regardless of the type of soil, using regression analysis.

Ulugergerli and Uyanik (2007) investigated the statistical relationships using 327 samples collected from different areas of Turkey and determined the upper and lower bound curves for estimating seismic velocity and relative density. Sitharam and Anbazhagan (2007) conducted multichannel analysis of surface waves (MASW) experiments in 38 locations in Bangalore city in India and created the relationships between $V_{\mathrm{S}}$ and the corrected SPT- $N$ value. Dikmen (2009) proposed the statistical relationships between $V_{\mathrm{S}}$ and SPT- $N$ value for all soil types, silty and clayey soil for Anatolia region in Turkey.

Maheshwari et al. (2010) calculated the relationships between $V_{\mathrm{S}}$ and corrected and uncorrected SPT- $N$ value for different soil types (all soil, sand and clay) for Chennai city in India. They 
found small differences in statistical analysis for the relationships with uncorrected $N$ value and the corrected $N$ value for hammer energy. This shows that both corrected and uncorrected relationships can estimate $V_{\mathrm{S}}$ with similar precision. Hafezi Moghaddas et al. (2010) analysed the variation of $V_{\mathrm{S}}$ and SPT- $N$ and developed the empirical relations between these two parameters for different fine and coarse grain soils and all types of soil in some areas of Mashhad. Mhaske and Choudhury (2011) collected the information about soil from different areas of Mumbai city in India and calculated the relationships between corrected and uncorrected $\operatorname{SPT}-N$ values with $V_{\mathrm{S}}$. Akin et al. (2011) studied the relationship between $V_{\mathrm{S}}$, SPT blow counts and soil characteristics as a function of depth.

Chatterjee and Choudhury (2013) proposed the empirical correlations between $V_{\mathrm{S}}$ and SPT- $N$ values (corrected/uncorrected) for various soil profiles of Kolkata city using nonlinear regression analysis. The authors collected extensive geotechnical data from 434 boreholes located across 75 sites in the city area. Sil and Sitharam (2013) presented a seismic site characterisation of Agartala city in the northeast of India. They conducted a geophysical test (MASW technique) at 27 locations and selected 27 SPT bore log profiles close to these locations for statistical analysis. They used site-specific data sets to develop correlations between $V_{\mathrm{S}}$ and $N$ value (corrected and uncorrected) to predict $V_{\mathrm{S}}$ based on available SPT- $N$ value. Fabbrocino et al. (2015) investigated the relationship between $V_{\mathrm{S}}$ and the blow number of standard penetration tests $\left(N_{\mathrm{SPT}}\right)$ with reference to the structurally complex formations located in a wide sector of the Southern Apennine chain (Italy). Tables 1 and 2 give a summary of the existing empirical relationships. Nearly all relationships used the functional form $V_{\mathrm{S}}=a \times N^{b}$ in which the constants $a$ and $b$ are determined by the statistical regression of the data.

\section{Materials and method}

\subsection{Study area}

Mashhad city, with an area of $204 \mathrm{~km}^{2}$ is the centre of Khorasan Razavi province and the second most populated city in Iran. This city is located at latitude $36.1-36.24^{\circ} \mathrm{N}$ and longitude $59.25-59.43^{\circ} \mathrm{E}$ in the northeast of Iran (figure 1). The population of this city is 2.77 million people according to the census in 2011, and its growth rate is about $2 \%$. Because of the holy shrine of the Imam Reza, this city receives more than 15 million pilgrims and tourists, yearly. Particularly during the last $15 \mathrm{yr}$, tourism, business, agriculture and immigration to this city have improved.

Mashhad city is placed on Mashhad plain which is covered with thick quaternary alluvial sediments. The sediments of the Mashhad plain come from Kashafrood River, which is the main drainage system of Mashhad plain, and the streams that originate from the southern parts of this city. Regarding the deposition source, from slate and phyllite rocks in the west and southwest of the city and also from the ultramafic outcrops in the southern heights towards the centre and the east of the plain, the grain size of the soil decreases and soil texture becomes finer (Akbari et al. 2011).

From the seismotectonical viewpoint, Mashhad city is located between the Koppe-Dagh foldedthrusted mountains from the northeast and the Binalood folded-thrusted mountains from the southwest. The vast plain of Mashhad-Ghuchan was formed in the junction of the two abovementioned provinces. Studies on the earthquakes of the area indicate that there were intense activities in the past centuries, especially in the 18th century (Berberian and Ghoreshi 1989). The existence of active faults (the north of Mashhad fault and the south of Mashhad fault) on both sides of the plain and within a small distance from the city is indicative of a high potential for earthquake risk in this region. In addition, the main active faults in this area are Toos fault, Kashafrood fault, Shandiz fault, the north of Neishaboor fault and Kheirabad fault (Azadi et al. 2010). Figure 1 shows the geological map of Mashhad city and the active faults in this area. Mashhad is not only the second most important city in Iran after Tehran the capital city, in terms of population, economics, industry, etc., but also the second city most exposed to the risk of natural disasters. This city in terms of the risk of earthquake is situated in the high risk zone, with 0.30-0.35 g maximum acceleration.

\subsection{Data collection}

The geotechnical data including results of soil classification, Atterberg limits, water content and unit weight, shear strength parameters and SPT were extracted from geotechnical engineering reports gathered from consulting engineering companies and soil mechanics laboratories. The geophysical 
Table 1. Proposed empirical relationships between uncorrected SPT-N and shear wave velocity.

\begin{tabular}{|c|c|c|c|c|c|c|}
\hline $\begin{array}{l}\text { Eq. } \\
\text { no. }\end{array}$ & Authors & Country & All soil types & Gravel & Sand & Clay \\
\hline 1 & $\begin{array}{l}\text { Ohba and Toriuma } \\
\text { (1970) }\end{array}$ & Japan & $V_{\mathrm{S}}=85.34 N^{0.31}$ & & & \\
\hline 2 & Shibata (1970) & Japan & & & $V_{\mathrm{S}}=31.7 N^{0.5}$ & \\
\hline 3 & Ohta et al. (1972) & Japan & & & $V_{\mathrm{S}}=87.2 N^{0.36}$ & \\
\hline 4 & $\begin{array}{l}\text { Ohsaki and Iwasaki } \\
\text { (1973) }\end{array}$ & Japan & $V_{\mathrm{S}}=81.38 N^{0.39}$ & & $V_{\mathrm{S}}=59.4 N^{0.47}$ & \\
\hline 5 & Imai $(1977)$ & Japan & $V_{\mathrm{S}}=91 N^{0.337}$ & & $V_{\mathrm{S}}=80.6 N^{0.331}$ & $V_{\mathrm{S}}=80.2 N^{0.292}$ \\
\hline 6 & $\begin{array}{l}\text { Ohta and Goto } \\
\text { (1978) }\end{array}$ & Japan & $V_{\mathrm{S}}=85.35 N^{0.348}$ & & & \\
\hline 7 & $\begin{array}{l}\text { Seed and Idriss } \\
\text { (1981) }\end{array}$ & USA & $V_{\mathrm{S}}=61 N^{0.5}$ & & & \\
\hline 8 & $\begin{array}{l}\text { Imai and Tonouchi } \\
(1982)\end{array}$ & Japan & $V_{\mathrm{S}}=97 N^{0.314}$ & & & \\
\hline 9 & Seed et al. (1983) & USA & & & $V_{\mathrm{S}}=56.4 N^{0.5}$ & \\
\hline 10 & $\begin{array}{l}\text { Sykora and Stokoe } \\
\text { (1983) }\end{array}$ & USA & & & $V_{\mathrm{S}}=100.5 N^{0.29}$ & \\
\hline 11 & Lee $(1990)$ & Taiwan & & & $V_{\mathrm{S}}=57.4 N^{0.49}$ & $V_{\mathrm{S}}=114.43 N^{0.31}$ \\
\hline 12 & Lee (1992) & Taiwan & $V_{\mathrm{S}}=76.2 N^{0.24}$ & & & $V_{\mathrm{S}}=138.4(N+1)^{0.242}$ \\
\hline 13 & $\begin{array}{l}\text { Pitilakis et al. } \\
\text { (1992) }\end{array}$ & Greece & & & $V_{\mathrm{S}}=162 N^{0.17}$ & \\
\hline 14 & $\begin{array}{l}\text { Athanasopoulos } \\
\text { (1995) }\end{array}$ & Greece & $V_{\mathrm{S}}=107.6 N^{0.36}$ & & & $V_{\mathrm{S}}=76.55 N^{0.445}$ \\
\hline 15 & $\begin{array}{l}\text { Raptakis et al. } \\
\text { (1995) }\end{array}$ & Greece & & $V_{\mathrm{S}}=192.4 N^{0.130}$ & & \\
\hline 16 & Kanai (1966) & Japan & $V_{\mathrm{S}}=19 N^{0.6}$ & & & \\
\hline 17 & Iyisan (1996) & Turkey & $V_{\mathrm{S}}=51.5 N^{0.516}$ & & & \\
\hline 18 & Jafari et al. (1997) & Iran & $V_{\mathrm{S}}=22 N^{0.85}$ & & & \\
\hline 19 & Kiku et al. (2001) & Japan & $V_{\mathrm{S}}=68.3 N^{0.292}$ & & & \\
\hline 20 & Jafari et al. (2002) & Iran & & & & $V_{\mathrm{S}}=27 N^{0.73}$ \\
\hline 21 & $\begin{array}{l}\text { Hasancebi and } \\
\text { Ulusay (2007) }\end{array}$ & Turkey & $V_{\mathrm{S}}=90 N^{0.309}$ & & $V_{\mathrm{S}}=90.82 N^{0.319}$ & $V_{\mathrm{S}}=97.89 N^{0.269}$ \\
\hline 22 & Dikmen (2009) & Turkey & $V_{\mathrm{S}}=58 N^{0.39}$ & & $V_{\mathrm{S}}=73 N^{0.33}$ & $V_{\mathrm{S}}=44 N^{0.48}$ \\
\hline 23 & $\begin{array}{l}\text { Maheshwari et al. } \\
\text { (2010) }\end{array}$ & India & $V_{\mathrm{S}}=95.64 N^{0.301}$ & & $V_{\mathrm{S}}=100.53 N^{0.265}$ & $V_{\mathrm{S}}=89.31 N^{0.358}$ \\
\hline 24 & $\begin{array}{l}\text { Hafezi Moghaddas } \\
\text { et al. (2010) }\end{array}$ & Iran & $V_{\mathrm{S}}=99 N^{0.53}$ & & $V_{\mathrm{S}}=80 N^{0.58}$ & $V_{\mathrm{S}}=45 N^{0.72}$ \\
\hline 25 & $\begin{array}{l}\text { Chatterjee and } \\
\text { Choudhury (2013) }\end{array}$ & India & $V_{\mathrm{S}}=78.21 N^{0.38}$ & & $V_{\mathrm{S}}=54.82 N^{0.53}$ & $V_{\mathrm{S}}=77.11 N^{0.39}$ \\
\hline
\end{tabular}

surveys and wave velocity measurements were done by Zamin Physic Pooya consulting company and used for this study.

\subsubsection{Downhole test}

In a downhole test, the source of seismic wave is placed at the ground surface near the borehole and a single receiver which is moveable in different depths or a series of receivers is installed at different depths in the borehole walls. All receivers are connected to a data recording system. The travel time of body waves ( $\mathrm{S}$ and $\mathrm{P}$ ) between each geophone and the source is recorded; then, the recorded time will be plotted vs. depth. Finally, using these plots, the $\mathrm{P}$ and $\mathrm{S}$ wave velocity are determined. After determining the wave velocity, the soil dynamic properties (the shear modulus, elastic modulus and Poisson's ratio) can be calculated. In this study, seismic measurements were performed in 84 sites through the downhole method based on ASTM-D7400 (2008) standard and the $V_{\mathrm{S}}$ 
Table 2. Proposed empirical relationships between corrected SPT-N and shear wave velocity.

\begin{tabular}{|c|c|c|c|c|c|c|}
\hline Authors & Eq. no. & Country & All soil types & Gravel & Sand & Clay \\
\hline Iyisan (1996) & 1 & Turkey & $V_{\mathrm{S}}=71.2 N_{60}^{0.440}$ & & & \\
\hline Rollins et al. (1998) & 2 & USA & & $V_{\mathrm{S}}=132 N_{60}^{0.320}$ & & \\
\hline Pitilakis et al. (1999) & 3 & Greece & & & $V_{\mathrm{S}}=145 N_{60}^{0.178}$ & $V_{\mathrm{S}}=132 N_{60}^{0.271}$ \\
\hline $\begin{array}{l}\text { Hasancebi and Ulusay } \\
(2007)\end{array}$ & 4 & Turkey & $V_{\mathrm{S}}=104.8 N_{60}^{0.260}$ & & $V_{\mathrm{S}}=131 N_{60}^{0.205}$ & $V_{\mathrm{S}}=107.6 N_{60}^{0.237}$ \\
\hline $\begin{array}{l}\text { Sitharam and Anbazhagan } \\
\text { (2008) }\end{array}$ & 5 & India & $V_{\mathrm{S}}=78\left(N_{60 \mathrm{CS}}\right)^{0.4}$ & & & \\
\hline Maheshwari et al. (2010) & 6 & India & $V_{\mathrm{S}}=90.75 N_{60}^{0.304}$ & & $V_{\mathrm{S}}=96.29 N_{60}^{0.266}$ & $V_{\mathrm{S}}=83.27 N_{60}^{0.365}$ \\
\hline $\begin{array}{l}\text { Chatterjee and } \\
\text { Choudhury (2013) }\end{array}$ & 7 & India & $V_{\mathrm{S}}=78.63\left(N_{1}\right)_{60}^{0.37}$ & & $V_{\mathrm{S}}=56.44\left(N_{1}\right)_{60}^{0.51}$ & $V_{\mathrm{S}}=78.03\left(N_{1}\right)_{60}^{0.38}$ \\
\hline
\end{tabular}

was calculated at every $2 \mathrm{~m}$ interval of the depth of boreholes. The positions of these boreholes are depicted in figure 1.

\subsubsection{SPT data collection}

Standard penetration test, usually known as SPT, is the oldest and most common in-situ test in soil investigations. This test is one of the most efficient in-situ tests for the fast and economical assessment of the geotechnical properties of soil layers and is used as one of the essential indicator for the design of structures. The SPT conducted through the standard method (ASTM-D1586 2011) is used for obtaining soil resistance against standard sampler penetration by consulting engineering companies and soil mechanics laboratories in Mashhad. This test is done in all geotechnical boreholes and at every $1.5-2 \mathrm{~m}$ of depth or in every layer change (whichever happens first). Based on this method, first a standard split-barrel sampler is sent into the borehole; then the sampler is driven into the ground by a $63.5 \mathrm{~kg}$ hammer-free falling from a height of $762 \mathrm{~mm}$ onto an anvil placed on top of the drill rod. The number of blows required for each $15 \mathrm{~cm}$ penetration of the sampler into the soil is recorded. The total number of blows needed for the second and third $15 \mathrm{~cm}$ penetration is reported as the standard penetration resistance or $N$ value. After completion of the test the sample inside the sampler can be collected and used for other experiments.

The reliable SPT data for this study were collected from geotechnical investigation reports carried out in various locations of Mashhad city. Data of as many as 1821 boreholes were collected but only data of 88 boreholes were used in this study.
Most of the boreholes are 30-35 $\mathrm{m}$ deep and about 10 boreholes are also drilled up to depths of 40-80 $\mathrm{m}$. The minimum and maximum recorded SPT$N$ is 8 and 157, respectively. Among the primary data set, about 217 measurements of SPT- $N$ were removed from the study because 40 of them were more than 100 and the rest were reported ' $>$ 50' that were recognised as missing data in the SPSS software. Usually, in the upper layers of soil, the SPT- $N$ value is small and the value increases gradually with the increase in depth. This increase in $N$ value may be because of density of layers due to overburden pressure of top soils. Of course, sometimes the existence of large masses of rock on the way of the sampler makes a false increase in the number of blows and might stop operation. Changes in SPT- $N$ and $V_{\mathrm{S}} v s$. depth for two selected boreholes have been shown in figure 2 .

\subsubsection{Subsurface conditions}

For determining the physical properties of soil samples obtained from drilled boreholes, laboratory tests including sieve test, Atterberg limit test, water content test, unit weight test, direct shear test, triaxial strength test and consolidation test were conducted. According to sieve test and the classification of the soil which was done according to unified soil classification system on samples obtained from 88 boreholes, it was revealed that the total samples tested $42 \%$ was sandy soil, followed by clayey soil with a frequency of $24 \%$, gravelly soil with a frequency of $21.3 \%$ and a limited number of silty soil $(8 \%)$ in some parts of the area. Laboratory tests show that the existing finegrained layers have a low plasticity and are mostly in classes CL and ML. The conducted experiments 


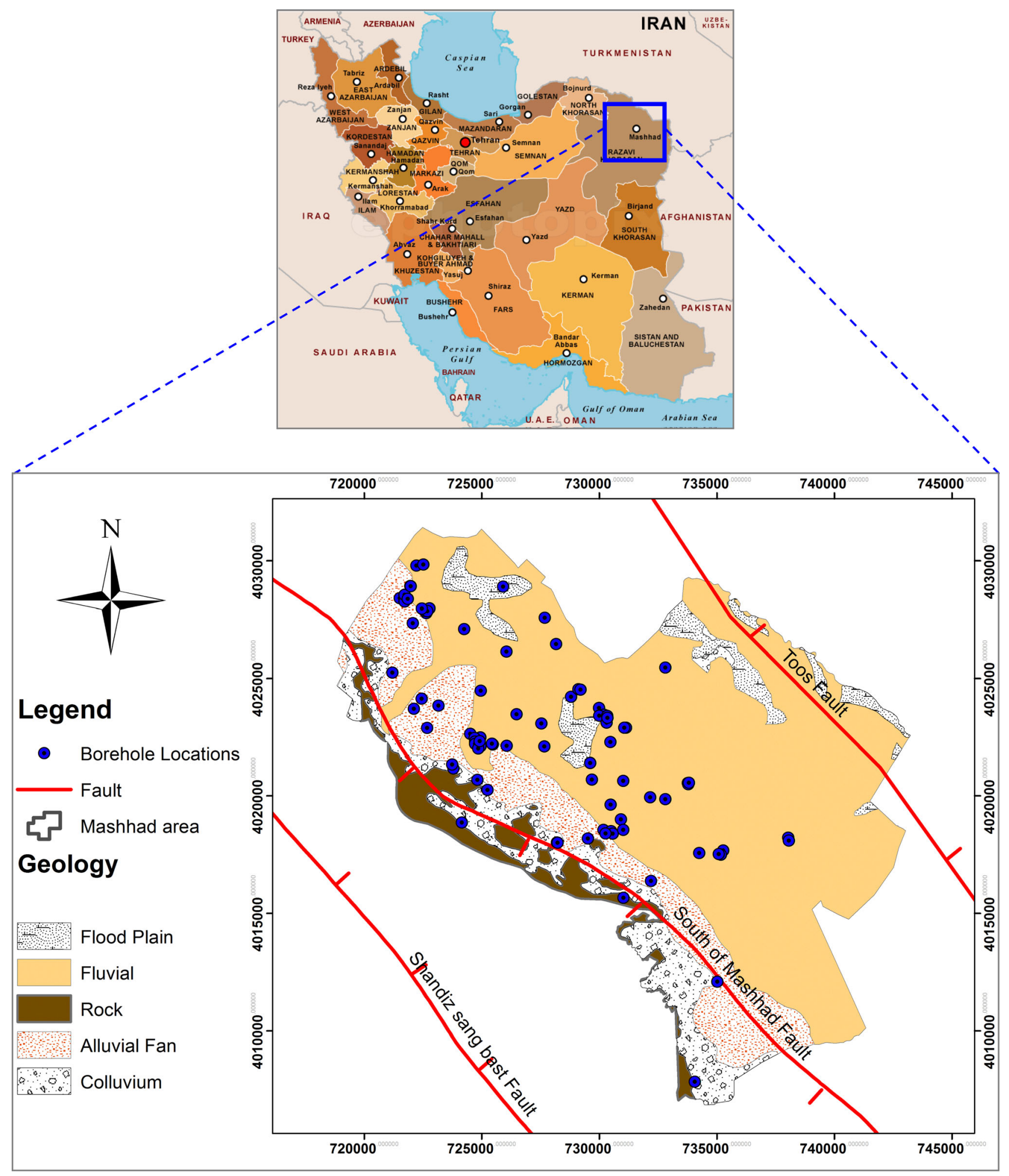

Figure 1. The geological map and active faults in Mashhad area with location of the drilled boreholes for geotechnical and geophysical studies in the city.

on 1097 samples showed that the dry unit weight in the site under study changed between 1.60 and 2.35 $\mathrm{g} / \mathrm{cm}^{3}$ for gravel, 1.57 and $2.33 \mathrm{~g} / \mathrm{cm}^{3}$ for sand, 1.55 and $2.15 \mathrm{~g} / \mathrm{cm}^{3}$ for silt and 1.43 and $2.22 \mathrm{~g} / \mathrm{cm}^{3}$ for clayey soil.
According to the data obtained from seismic explorations and as shown in figure 3, the shear wave velocity in low depths of soil is generally low; however, in all seismic profiles the relative increase in wave velocity can be observed as a result of 

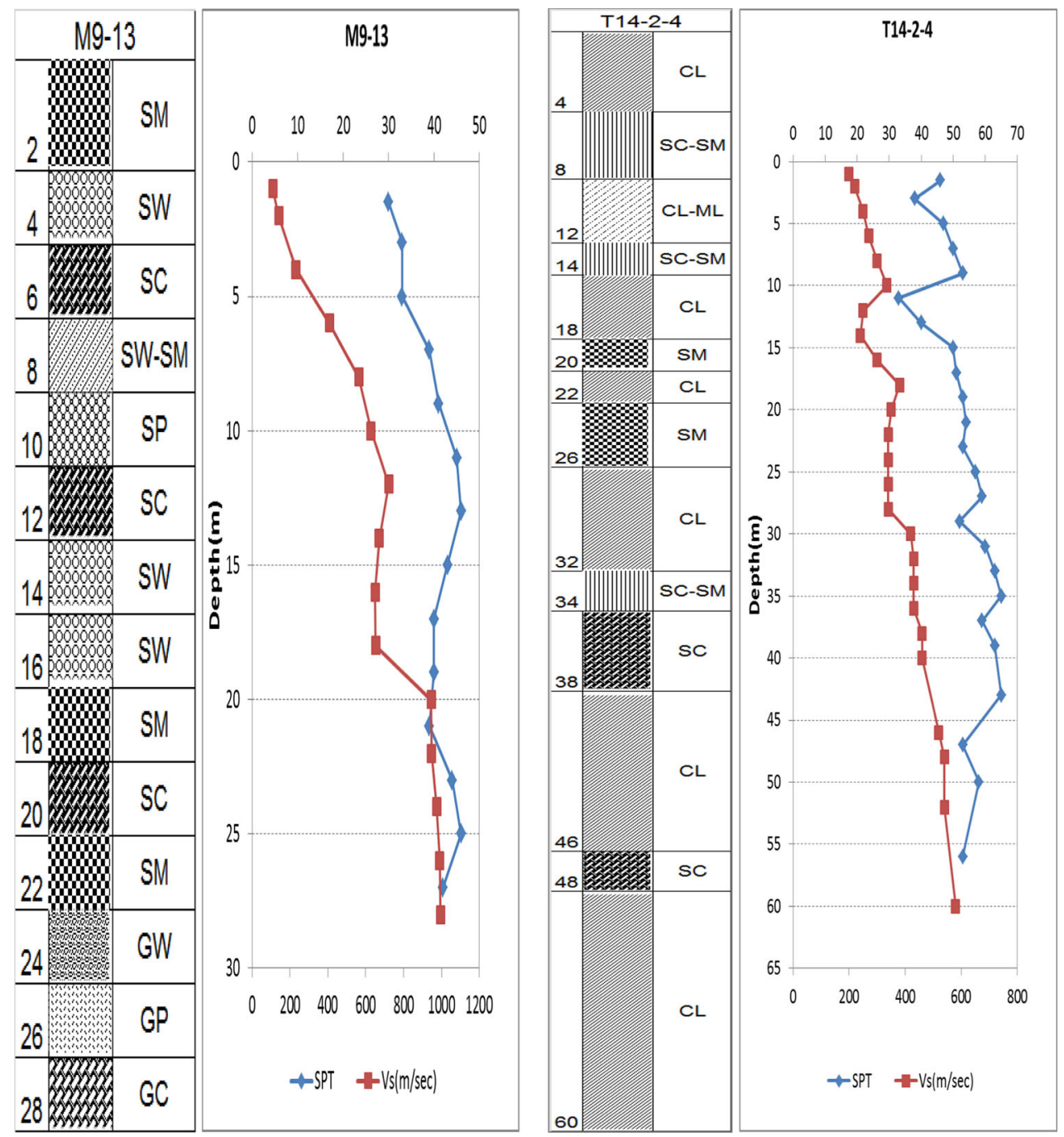

Figure 2. Shear wave velocity profiles and SPT changes vs. depth for two boreholes in the study area.

an increase in depth, being indicative of a rise in soil stiffness in depth. A significant fall in wave velocity at a depth of about $23-30 \mathrm{~m}$ is probably because of existence of the average level of groundwater level in these depths. This is indicated by two seismic profiles obtained through downhole method showing shear wave velocity in two selected boreholes as presented in figure 2 .

\section{Seismic site classification}

Iran is one of the most seismically active regions in the world that has experienced several catastrophic earthquakes, for example in Tabas $(1978$, $7.8 \mathrm{Ms}$ ), Manjil-Rudbar (1990, 7.4 Mw) and Bam (2003, 6.6 Mw). Iranian eastern cities are located in a moderate-to-high seismic region on young sediments and are prone to seismic hazards (Rahimi et al. 2012). Strong motions locally observed at a specific site when hit by a large earthquake are well known as the site effect which are caused by the weakness in physical properties of superficial soft sediments. The major factor which controls the site effect is shear wave velocities of the superficial sediments. Therefore, we can estimate the site effect or the amplification characteristics from the shear wave velocities of the near surface layers. Thus, $V_{\mathrm{S}}$ has been frequently used in designing models for the site response simulation and the earthquake recording interpretation, as well as design applications and building codes (Kramer 1996; Apostolidis et al. 2006; Lang and Schwarz 2006).

In earthquake geotechnical practice and predicting earthquake ground motion, the averaged $V_{\mathrm{S}}$ in the uppermost $30 \mathrm{~m}\left(V_{\mathrm{S} 30}\right)$ has been widely used to assess site condition and predict the potential amplification of seismic shaking (Holzer et al. 2005; Inazaki 2006). For instance, NEHRP uses $V_{\mathrm{S} 30}$ to 


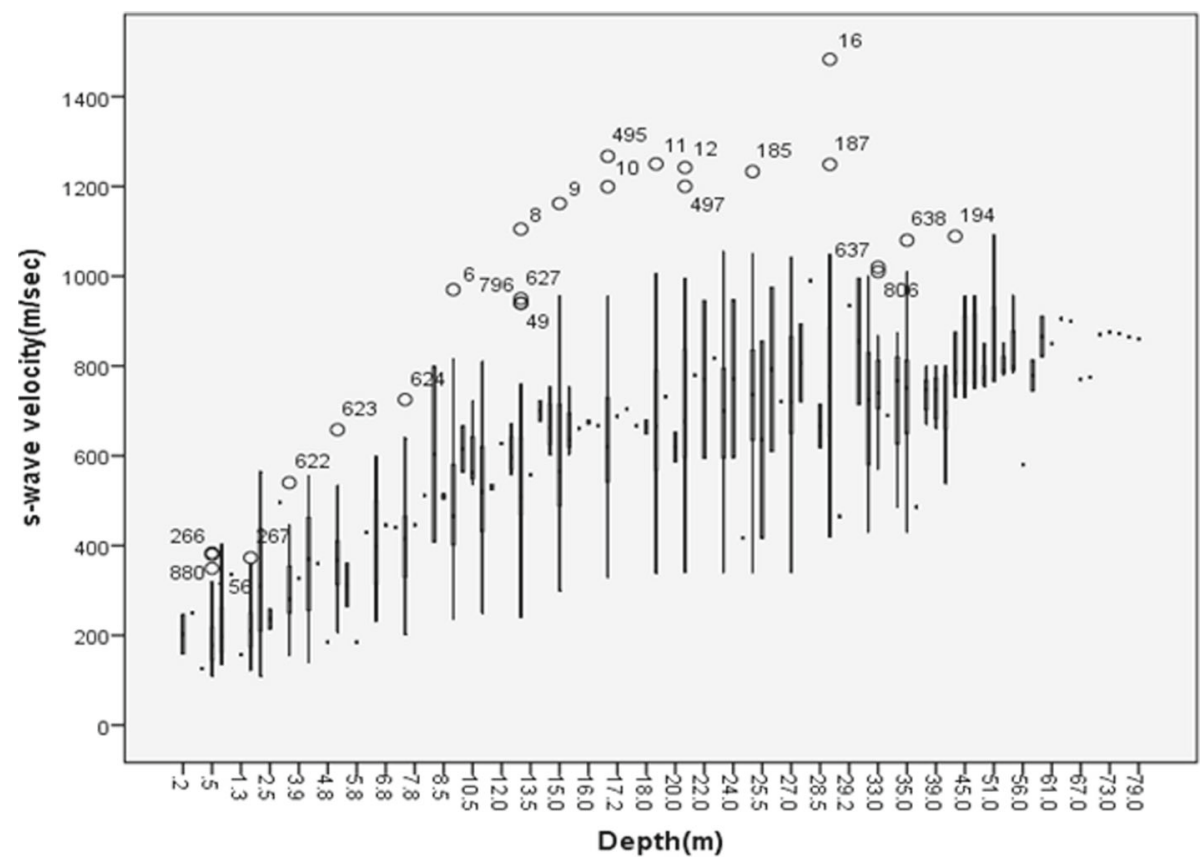

Figure 3. Changes in shear wave velocity with depth in all boreholes under study.

define site categories and to implement remediation provisions (BSSC 2001).

The seismic site classification system based on the average $V_{\mathrm{S}}$ on the uppermost $30 \mathrm{~m}$ of subsurface soil layers is defined by

$$
V_{\mathrm{S} 30}=\frac{30}{\sum_{i=1}^{n}\left(h_{i} / V_{i}\right)},
$$

where $h_{i}$ is the thickness of the $i$ th layer in $\mathrm{m}$ and $V_{i}$ is the $V_{\mathrm{S}}$ in $\mathrm{m} / \mathrm{s}$ of the $i$ th layer and $n$ is the total number of layers in the top $30 \mathrm{~m}$ (Borcherdt 1994; Williams et al. 2003). This technique for characterising the local site conditions from direct measurement of $V_{\mathrm{S}}$ through the top $30 \mathrm{~m}$ of material provides the most accurate characterisation of a site for purposes of estimating amplification factors. Information on other geotechnical parameters such as standard penetration resistance, undrained shear strength or void ratio can also be used to further refine estimates of shear wave velocity (Borcherdt 1994).

Table 3 shows the site classes adopted in NEHRP (BSSC 2001) and the criteria for site classification offered in the Iranian Code of Practice for Seismic Resistant Design of Buildings (Standard No. 2800). In Iranian seismic code, sites are classified into four groups that are related to similar categories of NEHRP design manual soil classes.
The site classification of the study area was done based on average $V_{\mathrm{S}}$ of the top $30 \mathrm{~m}\left(V_{\mathrm{S} 30}\right)$ using Iranian code (Standard No. 2800) and NEHRP. Table 4 presents the latitude and longitude of borehole locations and the related site classes according to these two classification systems. As shown in this table, most of the area comes under site class II $\left(375<V_{\mathrm{S} 30}<750\right)$ that is equivalent to class $\mathrm{C}$ of the NEHRP provisions. However, some locations are categorised as site class D. Therefore, most of area can be classified as stiff to dense soil.

As can be seen from the site classification map of Mashhad based on NEHRP (figure 4), the eastern areas of Mashhad showed a lower $V_{\mathrm{S}}$ value than the western areas of this city. This low velocity can be related to the geological conditions and soil texture in this area. As it was mentioned previously in the geology section of the study area, the grain size of soil becomes finer and soil density decreases as we move from west and southwest to east and northeast of the city.

Analysis of soil texture in drilled boreholes showed that in west Mashhad and in the areas close to the southern mountains, soil type is mostly sandy. It also showed the extension of this sandy area increased from surface to depth. In the central part of the city, at low depths clayey and sandy silt was observed and towards the deeper levels the percentage of sand increases. The eastern and northeastern areas of Mashhad are covered with 
Table 3. Soil profile classification according to 2800 standard of Iran and NEHRP design manual.

\begin{tabular}{|c|c|c|c|c|}
\hline \multicolumn{2}{|l|}{$\underline{\text { Site class }}$} & \multirow[b]{2}{*}{ Description } & \multicolumn{2}{|c|}{$V_{\mathrm{S} 30}(\mathrm{~m} / \mathrm{s})$} \\
\hline $\begin{array}{l}\text { Standard } \\
\text { No. } 2800\end{array}$ & NEHRP & & $\begin{array}{l}\text { Standard } \\
\text { No. } 2800\end{array}$ & NEHRP \\
\hline I & B & $\begin{array}{l}\text { a. Igneous rocks, stiff sedimentary rocks and massive metamorphic } \\
\text { rocks, conglomerate } \\
\text { b. Stiff soil with a thickness of more than } 30 \mathrm{~m} \text { above bedrock }\end{array}$ & $>750$ & $760-1500$ \\
\hline II & $\mathrm{C}$ & $\begin{array}{l}\text { a. Loose igneous rocks, loose sedimentary } \\
\text { rocks, foliated metamorphic rocks } \\
\text { b. Stiff soil having a thickness of more than } 30 \mathrm{~m} \text { above bedrock }\end{array}$ & $375-750$ & $360-760$ \\
\hline III & $\mathrm{D}$ & $\begin{array}{l}\text { a. Rocks that are disintegrated due to weathering } \\
\text { b. Soil with medium compact, layers of sand and gravel intra granular } \\
\text { bond and clay with intermediate compaction }\end{array}$ & $175-375$ & $180-360$ \\
\hline IV & $\mathrm{E}$ & $\begin{array}{l}\text { a. Soft deposits with high moisture content due to high level of water } \\
\text { table } \\
\text { b. Any soil profile containing clay with a minimum of } 6 \text { m and plastic } \\
\text { index and moisture content exceeding } 20 \% \text { and } 40 \% \text {, respectively }\end{array}$ & $<175$ & $<180$ \\
\hline
\end{tabular}

fine-grained soils at low depths and towards the deeper levels the percentage of silt increases. On the other hand, maximum alluvium thickness is in the east of the city which exceeds $200 \mathrm{~m}$.

According to the contour maps of the groundwater table, the water table in Mashhad city is tens of metres deep and the groundwater level changes within the range of $25-80 \mathrm{~m}$. The minimum depth of water table is observed in the northeast and eastern regions and the maximum depth of water table is in the northwest and south of the city. This can also be one of the main reasons for decrease of $V_{\mathrm{S} 30}$ in this part of Mashhad city.

\section{Data processing and results}

\subsection{Proposed relationships between SPT-N values and $V_{S}$}

The evaluation of a number of correlations presented in tables 1 and 2 shows that the majority of these relationships do not match with data collected from the study area. Therefore, new relationships are required for determining the $V_{\mathrm{S}}$ using the results of the standard penetration resistance test. Among the total data extracted from geotechnical reports related to Mashhad city, only in 84 sites ( 88 boreholes) there are data for both the standard penetration resistance and $V_{\mathrm{S}}$. After deletion of outlier data, as many as $424 V_{\mathrm{S}}$-SPT data pairs including 98 data pairs for gravelly soil, 168 data pairs for sandy soil, 32 data pairs for silty soil and 126 data pairs for clayey soil were obtained which were employed in the statistical analysis. In the present study, empirical correlations between $V_{\mathrm{S}}$ and both corrected and uncorrected $N$ values have been proposed.

The correlation between independent and dependent variables can be linear or nonlinear. It is of utmost importance to recognise a suitable linear or nonlinear function for model making. A suitable model should meet these conditions:

- it should be simple as much as possible,

- it has a larger determination coefficient $\left(R^{2}\right)$,

- it reduces the estimated errors.

If a model meets the above-mentioned conditions, it can be concluded that the model can predict the value of dependent variable more exactly than the other models. Therefore, after the regression models are made, different criteria can be used to determine which model provides a better measure of goodness of fit on data. Coefficient of determination $\left(R^{2}\right)$ and Pearson correlation coefficient $(R)$ are the most common indexes for comparing models, and cannot be used alone for the comparison and evaluation of the efficiency of these models.

In most studies the power model is used to show the correlation between $V_{\mathrm{S}}$ and $N$. In the present study, in order to recognise the type of relationship between $V_{\mathrm{S}}$ and $N$ and select a suitable linear or nonlinear function, different models were studied.

In this paper, in addition to the above coefficients, the sum of squares due to error (SSE), total sum of squares (SST), mean square error 
Table 4. Average shear wave velocity up to $30 \mathrm{~m}$ depth ( $V_{\mathrm{S} 30}$ ) of all soil types at various locations of Mashhad city and site classification according to 2800 standard of Iran and NEHRP design manual.

\begin{tabular}{|c|c|c|c|c|c|c|}
\hline $\begin{array}{l}\text { Borehole } \\
\text { code }\end{array}$ & Latitude & Longitude & $\begin{array}{l}\text { Depth of } \\
\text { borehole } \\
\quad(\mathrm{m})\end{array}$ & $\begin{array}{l}V_{\mathrm{S} 30} \\
(\mathrm{~m} / \mathrm{s})\end{array}$ & $\begin{array}{l}\text { Site class as } \\
\text { per standard } \\
\text { No. } 2800\end{array}$ & $\begin{array}{l}\text { Site class } \\
\text { as per } \\
\text { NEHRP }\end{array}$ \\
\hline D4-6-1 & 721520.00 & 4028408.00 & 30 & 519 & II & $\mathrm{C}$ \\
\hline D4-7-1 & 721723.20 & 4028269.20 & 30 & 557 & II & $\mathrm{C}$ \\
\hline D4-8-1 & 721724.00 & 4028554.00 & 30 & 545 & II & $\mathrm{C}$ \\
\hline D4-9-1 & 721859.00 & 4028381.00 & 30 & 495 & II & $\mathrm{C}$ \\
\hline E10-4-1 & 722678.56 & 4022897.50 & 30 & 416 & II & $\mathrm{C}$ \\
\hline E3-3-1 & 722519.00 & 4029842.00 & 30 & 532 & II & $\mathrm{C}$ \\
\hline E5-10-1 & 722779.00 & 4027984.00 & 30 & 510 & II & $\mathrm{C}$ \\
\hline E5-11-1 & 722643.00 & 4027787.00 & 30 & 573 & II & $\mathrm{C}$ \\
\hline E5-12-1 & 722575.00 & 4027880.00 & 30 & 496 & II & $\mathrm{C}$ \\
\hline E5-13-2 & 722689.00 & 4027866.00 & 30 & 448 & II & $\mathrm{C}$ \\
\hline E5-14-1 & 722459.00 & 4027969.00 & 30 & 451 & II & $\mathrm{C}$ \\
\hline E5-9-1 & 722071.64 & 4027353.33 & 30 & 545 & II & $\mathrm{C}$ \\
\hline E8-2-1 & 722449.00 & 4024137.00 & 48 & 527 & II & $\mathrm{C}$ \\
\hline E9-3-1 & 722113.36 & 4023709.07 & 31 & 673 & II & $\mathrm{C}$ \\
\hline F11-9-2 & 723743.00 & 4021336.00 & 30 & 529 & II & $\mathrm{C}$ \\
\hline F9-9-2 & 723165.60 & 4023844.00 & 30 & 504 & II & $\mathrm{C}$ \\
\hline G10-10-4 & 724510.90 & 4022648.19 & 56 & 460 & II & $\mathrm{C}$ \\
\hline G10-20-1 & 724704.00 & 4022469.00 & 30 & 596 & II & $\mathrm{C}$ \\
\hline G10-21-1 & 724719.00 & 4022318.00 & 30 & 639 & II & $\mathrm{C}$ \\
\hline G10-22-2 & 724718.00 & 4022220.00 & 30 & 460 & II & $\mathrm{C}$ \\
\hline G10-24-1 & 724854.00 & 4022023.00 & 39 & 539 & II & $\mathrm{C}$ \\
\hline G12-4-TF20 & 724816.40 & 4020687.00 & 30 & 334 & III & $\mathrm{D}$ \\
\hline G14-2-1 & 724159.00 & 4018871.00 & 30 & 639 & II & $\mathrm{C}$ \\
\hline G5-1-MB1 & 724255.90 & 4027107.00 & 30 & 326 & III & $\mathrm{D}$ \\
\hline G8-4-1 & 724961.00 & 4024477.00 & 30 & 379 & II & $\mathrm{C}$ \\
\hline H10-10-TP1 & 725473.00 & 4022192.00 & 30 & 329 & III & $\mathrm{D}$ \\
\hline H10-9-1 & 725433.00 & 4022223.00 & 30 & 542 & II & $\mathrm{C}$ \\
\hline H12-1-2 & 725245.84 & 4020255.16 & 30 & 618 & II & $\mathrm{C}$ \\
\hline H4-5-3 & 725907.52 & 4028898.65 & 30 & 624 & II & $\mathrm{C}$ \\
\hline I10-4-1 & 726064.00 & 4022133.00 & 30 & 535 & II & $\mathrm{C}$ \\
\hline I6-2-1 & 726055.00 & 4026141.00 & 30 & 462 & II & $\mathrm{C}$ \\
\hline J10-2-NC7 & 727663.60 & 4022105.00 & 30 & 525 & II & $\mathrm{C}$ \\
\hline J5-4-1 & 727685.00 & 4027590.00 & 30 & 674 & II & $\mathrm{C}$ \\
\hline K14-2-2 & 728204.00 & 4018020.00 & 34 & 319 & III & $\mathrm{D}$ \\
\hline K14-2-3 & 728233.00 & 4018010.00 & 35 & 455 & II & $\mathrm{C}$ \\
\hline K6-6-MB6 & 728164.00 & 4026467.00 & 30 & 471 & II & $\mathrm{C}$ \\
\hline K8-1-1 & 728797.40 & 4024217.13 & 30 & 614 & II & $\mathrm{C}$ \\
\hline L12-1NG5 & 729685.78 & 4020698.39 & 30 & 277 & III & $\mathrm{D}$ \\
\hline L14-4-MB15 & 729519.50 & 4018192.00 & 30 & 585 & II & $\mathrm{C}$ \\
\hline L8-5-1 & 729116.26 & 4024540.13 & 30 & 513 & II & $\mathrm{C}$ \\
\hline L8-8-1 & 729206.00 & 4024528.00 & 30 & 565 & II & $\mathrm{C}$ \\
\hline M10-18-1 & 730476.06 & 4022300.00 & 30 & 475 & II & $\mathrm{C}$ \\
\hline M13-3-1 & 730921.84 & 4019001.82 & 44 & 256 & III & $\mathrm{D}$ \\
\hline M13-5-1 & 730486.00 & 4019626.00 & 30 & 409 & II & $\mathrm{C}$ \\
\hline M14-10-1 & 730175.85 & 4018558.59 & 30 & 495 & II & $\mathrm{C}$ \\
\hline M14-11-1 & 730500.25 & 4018500.88 & 30 & 574 & II & $\mathrm{C}$ \\
\hline M14-22-1 & 730577.00 & 4018399.00 & 50 & 438 & II & $\mathrm{C}$ \\
\hline M14-8-1 & 730267.65 & 4018403.15 & 40 & 741 & II & $\mathrm{C}$ \\
\hline M9-13-1 & 730286.19 & 4023425.94 & 30 & 338 & III & $\mathrm{D}$ \\
\hline
\end{tabular}


Table 4. (Continued.)

\begin{tabular}{lcccccc}
\hline Borehole & Latitude & Longitude & $\begin{array}{c}\text { Depth of } \\
\text { borehole } \\
(\mathrm{m})\end{array}$ & $\begin{array}{c}V_{\text {S30 }} \\
(\mathrm{m} / \mathrm{s})\end{array}$ & $\begin{array}{c}\text { Site class as } \\
\text { per standard } \\
\text { No. 2800 }\end{array}$ & $\begin{array}{c}\text { Site class } \\
\text { as per } \\
\text { NEHRP }\end{array}$ \\
\hline M9-16-TP1 & 730185.00 & 4023458.00 & 35 & 421 & II & C \\
M9-17-4 & 730002.00 & 4023416.00 & 35 & 418 & II & C \\
M9-2-1 & 731134.60 & 4022905.37 & 36 & 484 & II & C \\
M9-2-2 & 731065.86 & 4022909.09 & 36 & 397 & II & C \\
M9-3-1 & 730317.94 & 4023123.95 & 30 & 406 & II & C \\
M9-8-1 & 730353.64 & 4023329.04 & 30 & 781 & I & B \\
N14-4-1-1 & 731022.18 & 4018555.43 & 30 & 555 & II & C \\
O13-11-2 & 732169.00 & 4019944.00 & 30 & 406 & II & C \\
O13-7-1 & 732815.27 & 4019859.09 & 80 & 573 & II & C \\
O16-5-TF10 & 732206.60 & 4016382.00 & 30 & 392 & II & C \\
O7-5-1 & 732811.00 & 4025462.00 & 44 & 320 & III & D \\
P12-6-2-2 & 733772.00 & 4020552.00 & 50 & 396 & II & C \\
P12-6-3-3 & 733786.00 & 4020497.00 & 50 & 430 & II & C \\
P12-6-4-4 & 733813.00 & 4020557.00 & 50 & 463 & II & C \\
P15-13-1 & 735275.00 & 4017680.00 & 44 & 304 & III & D \\
Q13-25-1 & 734251.62 & 4017575.67 & 40 & 340 & III & D \\
R15-6-2 & 735171.24 & 4017499.33 & 60 & 389 & II & C \\
R15-9-3 & 735083.00 & 4017531.00 & 30 & 572 & II & C \\
R20-3-TF5 & 735020.10 & 4012098.00 & 30 & 461 & II & C \\
R24-1-TF0 & 734060.60 & 4007832.00 & 30 & 429 & II & C \\
T14-2-3 & 738038.01 & 4018224.78 & 40 & 407 & II & C \\
T14-2-4 & 738066.00 & 4018101.00 & 60 & 300 & III & D \\
\hline
\end{tabular}

(MSE) and root mean square error (RMSE) were compared. The above statistics were calculated through the following equations:

$$
\begin{aligned}
\mathrm{SSE} & =\sum_{i=1}^{n}\left(m_{i}-p_{i}\right)^{2}, \\
\mathrm{SST} & =\sum_{i=1}^{n}\left(m_{i}-\bar{m}\right)^{2}, \\
\mathrm{SSR} & =\sum_{i=1}^{n}\left(p_{i}-\bar{m}\right)^{2}, \\
\mathrm{SST} & =\mathrm{SSR}+\mathrm{SSE}, \\
R^{2} & =\frac{\mathrm{SSR}}{\mathrm{SST}}=1-\frac{\mathrm{SSE}}{\mathrm{SST}}, \\
\mathrm{MSE} & =\frac{\sum_{i=1}^{n}\left(m_{i}-p_{i}\right)^{2}}{n}, \\
\mathrm{RMSE} & =\sqrt{\frac{\sum_{i=1}^{n}\left(m_{i}-p_{i}\right)^{2}}{n},}
\end{aligned}
$$

where $m_{i}$ is the measured value, $p_{i}$ is the predicted value, $\bar{m}$ is the mean of measured values and $n$ is the number of data presented in the database.
The best-possible fit is obtained if every observation lies on the least-square line. Therefore, for a perfect fit, we would have $\mathrm{SSE}=0$, and the ratio $\mathrm{SSR} / \mathrm{SST}=1$. RMSE and MSE are popular formulas to measure the error rate of a regression model; however, they can only be compared between models whose errors are measured in the same units.

Using the SPSS software, eight models were fit on the data and then the value of the above-mentioned criteria was calculated for each model. As shown in table 5, the power model shows higher values of coefficient of determination and correlation coefficient and lower values of error. Therefore, it is selected as the best model to show the correlation between uncorrected $V_{\mathrm{S}}$ and $N$. This finding is also consistent with the findings of the previous researchers who have proposed a power function between $V_{\mathrm{S}}$ and $\mathrm{SPT}-N$ value. In order to study the type of suitable model for the correlation between the corrected $N$ value and $V_{\mathrm{S}}$, a similar procedure was used and the results are presented in table 6 . In this case, the power model is also selected as the optimal model with the lowest error value and the highest correlation coefficient. 

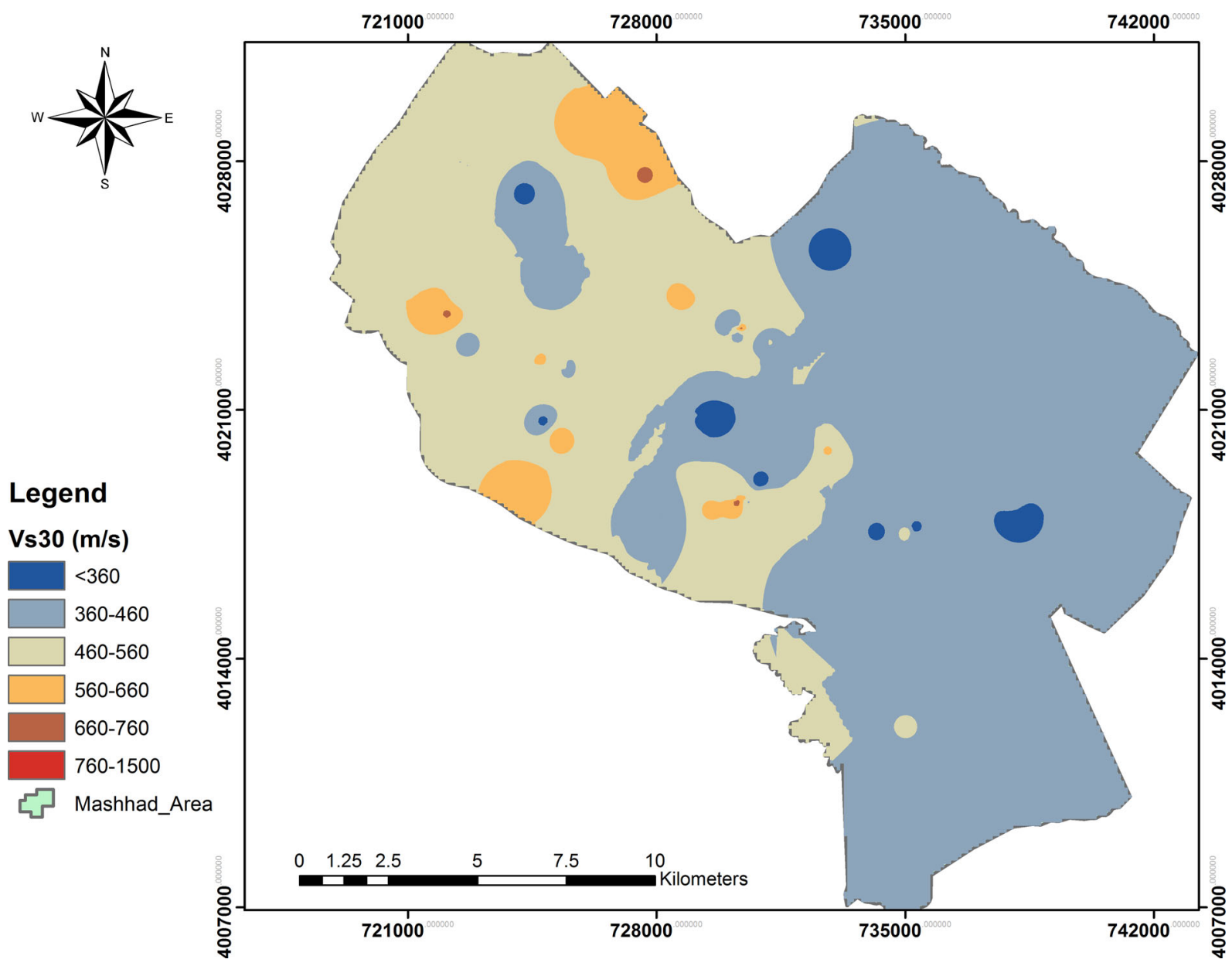

Figure 4. NEHRP classification based on shear wave velocity $\left(V_{\mathrm{S} 30}\right)$ for Mashhad city.

Table 5. Evaluation criteria between regression models for uncorrected $V_{S}-N$ correlations.

\begin{tabular}{lccccrr}
\hline Model & SSE & SST & $R^{2}$ & $R$ & MSE & RMSE \\
\hline Power & 3787394.881 & 9638264.881 & 0.607 & 0.779 & 8932.535 & 94.512 \\
$S$ & 3941937.150 & 9638264.881 & 0.591 & 0.769 & 9297.022 & 96.421 \\
Cubic & 3965118.764 & 9638264.881 & 0.589 & 0.767 & 9351.695 & 96.704 \\
Logarithmic & 3979414.058 & 9638264.881 & 0.587 & 0.766 & 9385.411 & 96.878 \\
Quadratic & 4035031.798 & 9638264.881 & 0.581 & 0.762 & 9516.584 & 97.553 \\
Linear & 4310721.605 & 9638264.881 & 0.553 & 0.743 & 10166.796 & 100.831 \\
Exponential & 4568194.263 & 9638264.881 & 0.526 & 0.725 & 10774.043 & 103.798 \\
Inverse & 4599123.029 & 9638264.881 & 0.523 & 0.723 & 10846.988 & 104.149 \\
\hline
\end{tabular}

Table 6. Evaluation criteria between regression models for corrected $V_{\mathrm{S}}-N$ correlations.

\begin{tabular}{lcccccc}
\hline Model & SSE & SST & $R^{2}$ & $R$ & MSE & RMSE \\
\hline Power & 1497200.687 & 3508978.185 & 0.573 & 0.757 & 3531.134 & 59.423 \\
Cubic & 1507667.324 & 3508978.185 & 0.570 & 0.755 & 3555.819 & 59.631 \\
Quadratic & 1508214.182 & 3508978.185 & 0.570 & 0.755 & 3557.109 & 59.642 \\
Linear & 1535654.907 & 3508978.185 & 0.562 & 0.750 & 3621.828 & 60.182 \\
Logarithmic & 1568075.980 & 3508978.185 & 0.553 & 0.744 & 3698.292 & 60.814 \\
Exponential & 1638846.560 & 3508978.185 & 0.533 & 0.730 & 3865.204 & 62.171 \\
$S$ & 1663964.797 & 3508978.185 & 0.526 & 0.725 & 3924.445 & 62.645 \\
Inverse & 1930304.178 & 3508978.185 & 0.450 & 0.671 & 4552.604 & 67.473
\end{tabular}




\subsubsection{Uncorrected $V_{S}-N$ correlations}

In the first step, new empirical equations were developed between measured $V_{\mathrm{S}}$ and uncorrected $N$ values for various soil types (i.e., all soil types, gravelly soil, sandy soil and clayey soil). Since the number of data for silty soil was low and insufficient for an accurate analysis, this part of data was excluded from evaluation. The following new equations with their correlation coefficients $(R)$ are obtained between uncorrected $N$ values and measured $V_{S}(\mathrm{~m} / \mathrm{s})$ for four soil categories mentioned above:

$$
\begin{aligned}
& V_{\mathrm{S}}=118.58 N^{0.452}, \quad R=0.779, \quad \text { all soils, } \quad(9 \\
& V_{\mathrm{S}}=97.27 N^{0.503}, \quad R=0.790, \quad \text { gravelly soils },
\end{aligned}
$$

$$
V_{\mathrm{S}}=135.52 N^{0.415}, \quad R=0.764, \quad \text { sandy soils, }
$$

$$
V_{\mathrm{S}}=123.88 N^{0.445}, \quad R=0.771, \quad \text { clayey soils. }
$$

The scattering of data points and the curves relating to equations (9)-(12) are depicted in figure 5(a). Moreover, comparison between measured $V_{\mathrm{S}}$ and the predicted $V_{\mathrm{S}}$ using new equations are shown in figure $5(\mathrm{~b})$. The plotted data points are all scattered between lines with a slope of $1: 2$ and 1:0.5. Most of the data are plotted close to the line 1:1; however, for data points having $V_{\mathrm{S}}$ less than $400 \mathrm{~m} / \mathrm{s}$, the velocity is overestimated and for points having a velocity more than $800 \mathrm{~m} / \mathrm{s}$, the velocity is underestimated.

\subsubsection{Corrected $V_{S}-N$ correlations}

There are numerous factors that are permitted by ASTM-D1586 (2011) and that affect the $N$ value. Correction factors have been proposed by various authors to account for factors such as the drill stem length and type, the type of anvil, the blow rate, the use of liners or borehole fluid and the type of hammer (Sherif Aggour and Rose Radding 2001). Hence, the SPT- $N$ value corrected for overburden stress, rod length, borehole diameter and sampling method is given by

$$
\left(N_{1}\right)_{60}=N_{\mathrm{m}} \cdot C_{\mathrm{N}} \cdot C_{\mathrm{E}} \cdot C_{\mathrm{B}} \cdot C_{\mathrm{R}} \cdot C_{\mathrm{S}},
$$

where $N_{\mathrm{m}}$ is the measured standard penetration resistance, $C_{\mathrm{N}}$ is the factor to normalise $N_{\mathrm{m}}$ to a common reference effective overburden stress, $C_{\mathrm{E}}$ is the correction for hammer energy ratio (ER), $C_{\mathrm{B}}$ is the correction factor for borehole diameter, $C_{\mathrm{R}}$ is the correction factor for rod length and $C_{\mathrm{S}}$ is the correction for samplers with or without liners.

Because $\mathrm{SPT}-N$ values increase with increasing effective overburden stress, an overburden stress correction factor is applied (Seed and Idriss 1982). This factor is commonly calculated from the following equation (Liao and Whitman 1986):

$$
C_{\mathrm{N}}=\left(P_{\mathrm{a}} / \sigma_{v 0}^{\prime}\right)^{0.5},
$$

where $C_{\mathrm{N}}$ normalises $N_{\mathrm{m}}$ to an effective overburden pressure $\sigma_{v 0}^{\prime}$ of approximately $100 \mathrm{kPa}(1 \mathrm{~atm})$ $\mathrm{Pa} . C_{\mathrm{N}}$ should not exceed a value of 1.7 . Kayen et al. (1992) suggested the following equation, which limits the maximum $C_{\mathrm{N}}$ value to 1.7 , and in these writers' opinion, provides a better fit to the original curve specified by Seed and Idriss (1982):

$$
C_{\mathrm{N}}=2.2 /\left(1.2+\sigma_{v 0}^{\prime} / P_{\mathrm{a}}\right) .
$$

Either equation may be used for routine engineering applications, but in this study the second formula was used for correction $N$ values. Skempton (1986) suggested and Robertson and Wride (1998) updated correction factors for rod lengths $<10 \mathrm{~m}$, borehole diameters outside the recommended interval $(65-125 \mathrm{~mm})$ and sampling tubes without liners. Table 7 shows the SPT correction procedure for one borehole in the centre of Mashhad city. The depth to ground water in this location was more than $40 \mathrm{~m}$. Most of geotechnical engineering companies use safety hammer in Iran. Therefore, the $C_{\mathrm{E}}=1$ was taken into account. Corrections of the rod length, borehole diameter and the sampling method were performed using table 8 .

The SPT- $N$ values measured in the field were corrected by applying the above-mentioned correction factors. The correlation between corrected SPT- $N$ values $\left(N_{1}\right)_{60}$ and $V_{\mathrm{S}}$ for all types of soil, gravelly soil, sandy soil and clayey soil were developed using regression analysis and the results are shown in figure $6(\mathrm{a})$ :

$$
V_{\mathrm{S}}=61.24\left(N_{1}\right)_{60}^{0.544}, \quad R=0.757, \quad \text { all soils, }
$$

$V_{\mathrm{S}}=54.58\left(N_{1}\right)_{60}^{0.591}, \quad R=0.731, \quad$ gravelly soils, 
(a)
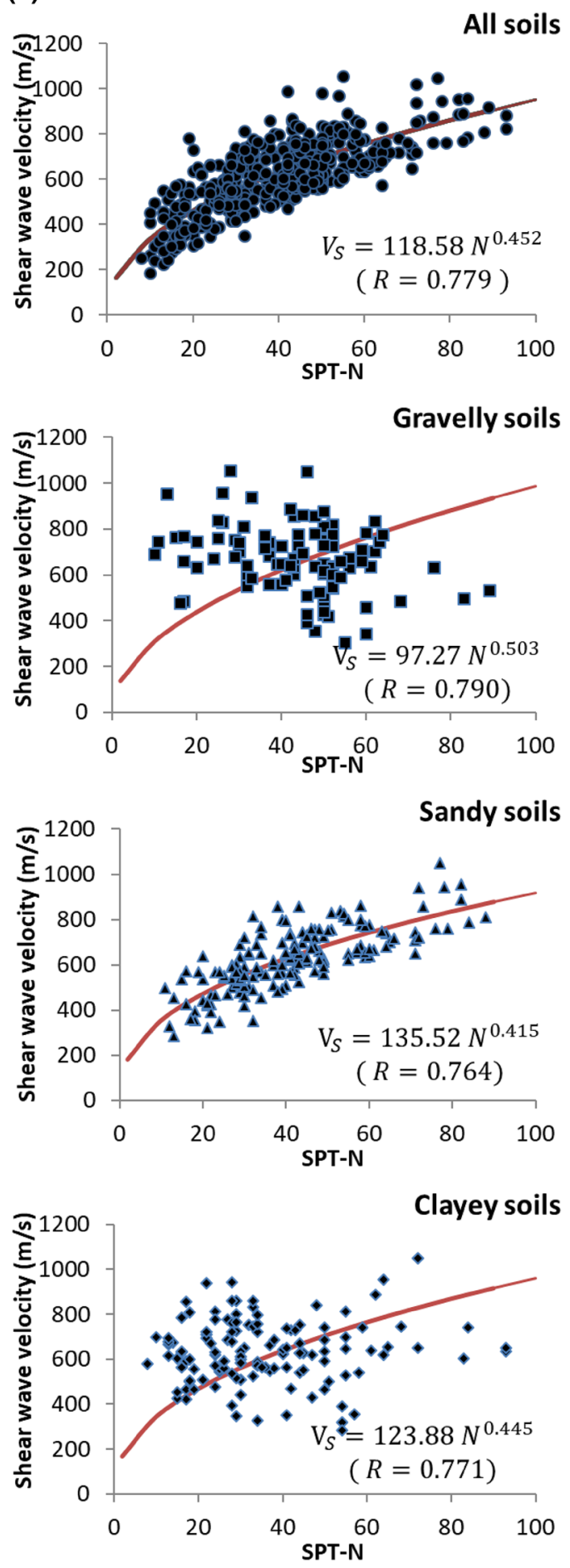

(b)
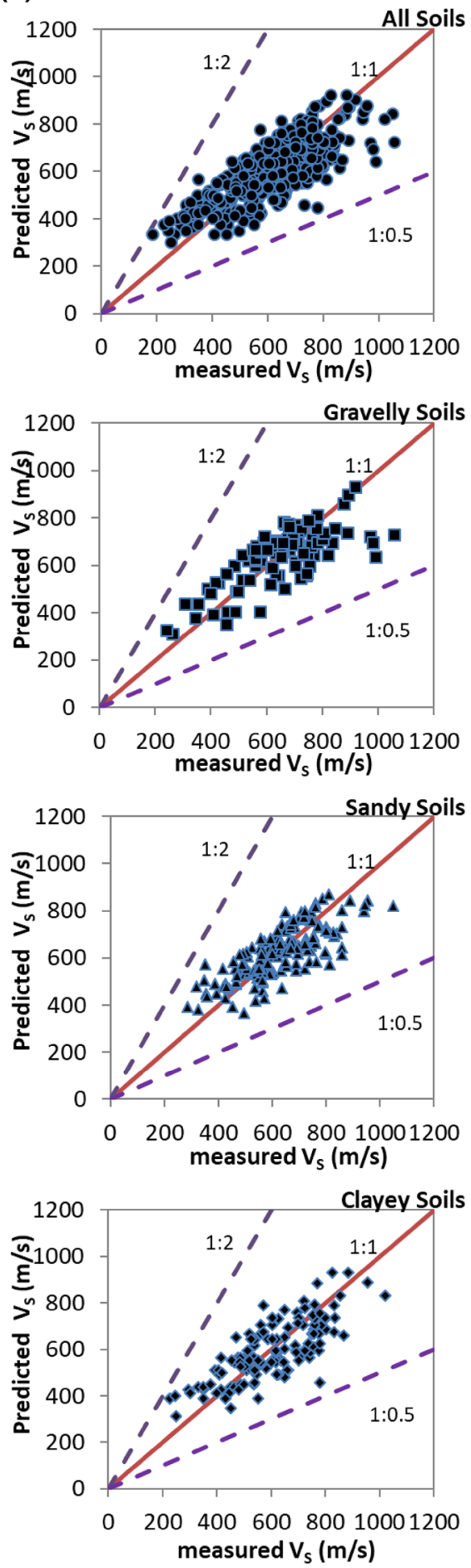

Figure 5. (a) Correlation between $V_{\mathrm{S}}$ and $\operatorname{SPT}-N$ value for all soil types, gravelly soil, sandy soil and clayey soil and (b) measured shear wave velocity vs. estimated shear wave velocity for four groups of soil.

$V_{\mathrm{S}}=69.18\left(N_{1}\right)_{60}^{0.506}, \quad R=0.726, \quad$ sandy soils

$V_{\mathrm{S}}=47.64\left(N_{1}\right)_{60}^{0.617}, \quad R=0.716, \quad$ clayey soils.
The plotted data points are all scattered between lines with a slope of 1:2 and 1:0.5 in figure 6(b). When the correlation coefficients obtained by equations (9-12) are compared with equations (1619), from the results it can be seen that a more 
Table 7. Correction of SPT-N values for one borehole in the centre of Mashhad city.

\begin{tabular}{|c|c|c|c|c|c|c|c|c|c|c|c|}
\hline $\begin{array}{l}\text { Borehole } \\
\text { code }\end{array}$ & $\begin{array}{l}\text { Depth } \\
(\mathrm{m})\end{array}$ & SPT & $\begin{array}{c}\text { Density } \\
\left(\mathrm{kN} / \mathrm{m}^{3}\right)\end{array}$ & $\begin{array}{c}\sigma_{V} \\
\left(\mathrm{kN} / \mathrm{m}^{2}\right)\end{array}$ & $\begin{array}{c}\sigma_{v}^{\prime} \\
\left(\mathrm{kN} / \mathrm{m}^{2}\right)\end{array}$ & $C_{\mathrm{N}}$ & $C_{\mathrm{E}}$ & $C_{\mathrm{B}}$ & $C_{\mathrm{R}}$ & $C_{\mathrm{S}}$ & $\left(N_{1}\right)_{60}$ \\
\hline M9-2 & 1.5 & 13.0 & 17.6 & 26.5 & 26.5 & 1.5 & 1.0 & 1.0 & 0.8 & 1.0 & 14.6 \\
\hline M9-2 & 3.0 & 14.0 & 17.6 & 52.9 & 52.9 & 1.3 & 1.0 & 1.0 & 0.8 & 1.0 & 14.2 \\
\hline M9-2 & 5.0 & 13.0 & 17.9 & 89.7 & 89.7 & 1.0 & 1.0 & 1.0 & 0.9 & 1.0 & 11.6 \\
\hline M9-2 & 7.0 & 16.0 & 18.1 & 127.0 & 127.0 & 0.9 & 1.0 & 1.0 & 1.0 & 1.0 & 13.5 \\
\hline M9-2 & 11.0 & 26.0 & 18.6 & 204.9 & 204.9 & 0.7 & 1.0 & 1.0 & 1.0 & 1.0 & 17.6 \\
\hline M9-2 & 13.0 & 25.0 & 18.6 & 242.2 & 242.2 & 0.6 & 1.0 & 1.0 & 1.0 & 1.0 & 15.2 \\
\hline M9-2 & 15.0 & 30.0 & 18.6 & 279.4 & 279.4 & 0.6 & 1.0 & 1.0 & 1.0 & 1.0 & 16.5 \\
\hline M9-2 & 17.0 & 29.0 & 18.6 & 316.7 & 316.7 & 0.5 & 1.0 & 1.0 & 1.0 & 1.0 & 14.6 \\
\hline M9-2 & 19.0 & 29.0 & 19.6 & 372.5 & 372.5 & 0.4 & 1.0 & 1.0 & 1.0 & 1.0 & 13.0 \\
\hline M9-2 & 21.0 & 29.0 & 19.6 & 411.8 & 411.8 & 0.4 & 1.0 & 1.0 & 1.0 & 1.0 & 12.0 \\
\hline M9-2 & 23.0 & 21.0 & 19.6 & 451.0 & 451.0 & 0.4 & 1.0 & 1.0 & 1.0 & 1.0 & 8.1 \\
\hline M9-2 & 25.0 & 13.0 & 19.6 & 490.2 & 490.2 & 0.4 & 1.0 & 1.0 & 1.0 & 1.0 & 4.7 \\
\hline M9-2 & 27.0 & 25.0 & 19.6 & 529.4 & 529.4 & 0.3 & 1.0 & 1.0 & 1.0 & 1.0 & 8.5 \\
\hline M9-2 & 29.0 & 28.0 & 19.6 & 568.6 & 568.6 & 0.3 & 1.0 & 1.0 & 1.0 & 1.0 & 8.9 \\
\hline M9-2 & 31.0 & 24.0 & 19.6 & 607.8 & 607.8 & 0.3 & 1.0 & 1.0 & 1.0 & 1.0 & 7.3 \\
\hline M9-2 & 35.0 & 45.0 & 19.6 & 686.3 & 686.3 & 0.3 & 1.0 & 1.0 & 1.0 & 1.0 & 12.3 \\
\hline
\end{tabular}

Table 8. Correction factors for SPT (modified from Skempton (1986) as listed by Robertson and Wride (1998)).

\begin{tabular}{llll}
\hline Factor & \multicolumn{1}{c}{ Equipment variable } & Term & Correction \\
\hline Overburden pressure & - & $C_{\mathrm{N}}$ & $\left(P_{\mathrm{a}} / \sigma_{v 0}^{\prime}\right)^{0.5}$ \\
Overburden pressure & - & $C_{\mathrm{N}}$ & $C_{\mathrm{N}} \leq 1.7$ \\
Energy ratio & Donut hammer & $C_{\mathrm{E}}$ & $0.5-1.0$ \\
Energy ratio & Safety hammer & $C_{\mathrm{E}}$ & $0.7-1.2$ \\
Energy ratio & Automatic-trip Donut type hammer & $C_{\mathrm{E}}$ & $0.8-1.3$ \\
Borehole diameter & $65-115 \mathrm{~mm}$ & $C_{\mathrm{B}}$ & 1.0 \\
Borehole diameter & $150 \mathrm{~mm}$ & $C_{\mathrm{B}}$ & 1.05 \\
Borehole diameter & $200 \mathrm{~mm}$ & $C_{\mathrm{B}}$ & 1.15 \\
Rod length & $<3 \mathrm{~m}$ & $C_{\mathrm{R}}$ & 0.75 \\
Rod length & $3-4 \mathrm{~m}$ & $C_{\mathrm{R}}$ & 0.8 \\
Rod length & $4-6 \mathrm{~m}$ & $C_{\mathrm{R}}$ & 0.85 \\
Rod length & $6-10 \mathrm{~m}$ & $C_{\mathrm{R}}$ & 0.95 \\
Rod length & $10-30 \mathrm{~m}$ & $C_{\mathrm{R}}$ & 1.0 \\
Sampling method & Standard sampler & $C_{\mathrm{S}}$ & 1.0 \\
Sampling method & Sampler without liners & $C_{\mathrm{S}}$ & $1.1-1.3$ \\
\hline
\end{tabular}

accurate estimation of $V_{\mathrm{S}}$ and better correlations were obtained when uncorrected $N$ values were used.

\subsection{Assessment of the appropriateness of regression model by graphical residual analysis}

There are several statistical methods for model validation but the first and simplest way is residual analysis. There are various types of the residual plots for a regression model to assess the suitability of the model. Correlation coefficient and coefficient of determination are also useful for the validation of regression model. For this study, the regression residuals were plotted vs. SPT and predicted $V_{\mathrm{S}}$ for all soil types, gravelly soil, sandy and clayey soil (figure $7 \mathrm{a}-\mathrm{c}$ ) to analyse the appropriateness of proposed correlations. Histograms in figure 7(a) show a normal like status of residuals in all groups. Figure 7(b) depicts the normal probability plots of residuals ( $\mathrm{p}-\mathrm{p}$ plot) for the four mentioned groups of soil. These figures show that the data points are scattered on the diagonal lines indicating good fitness of regression 
(a)

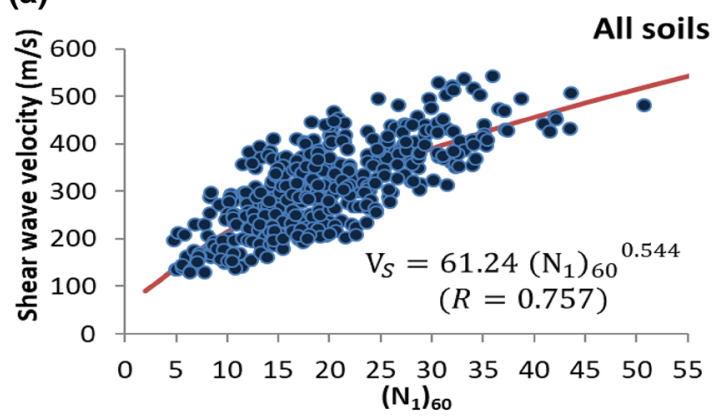

Gravelly soils

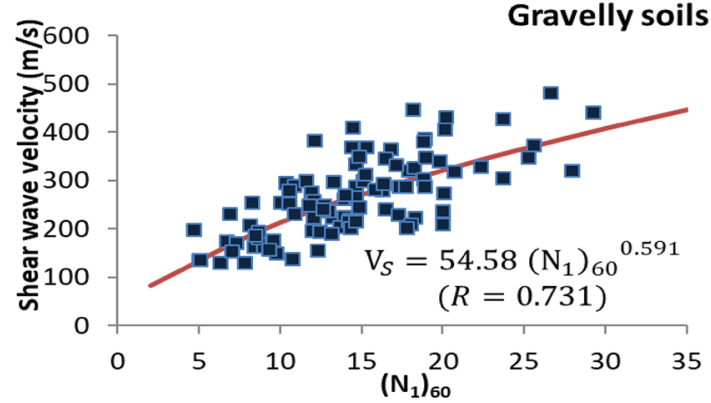

Sandy soils

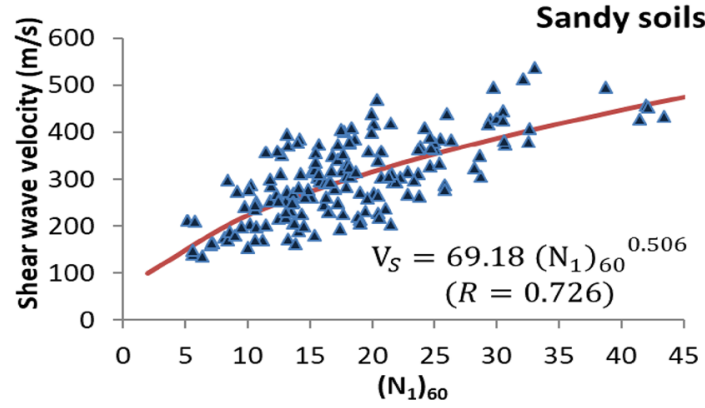

Clayey soils

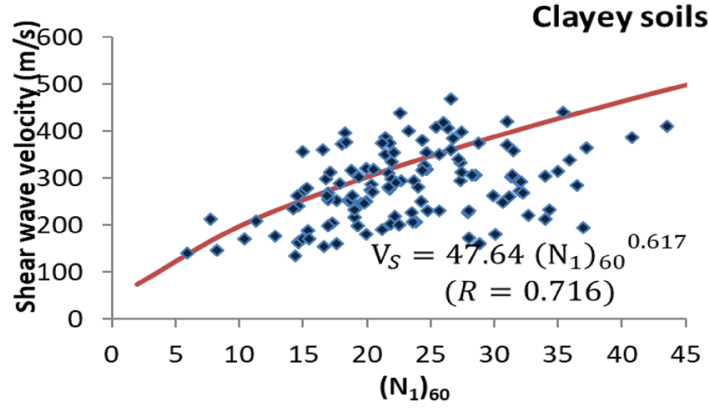

(b)
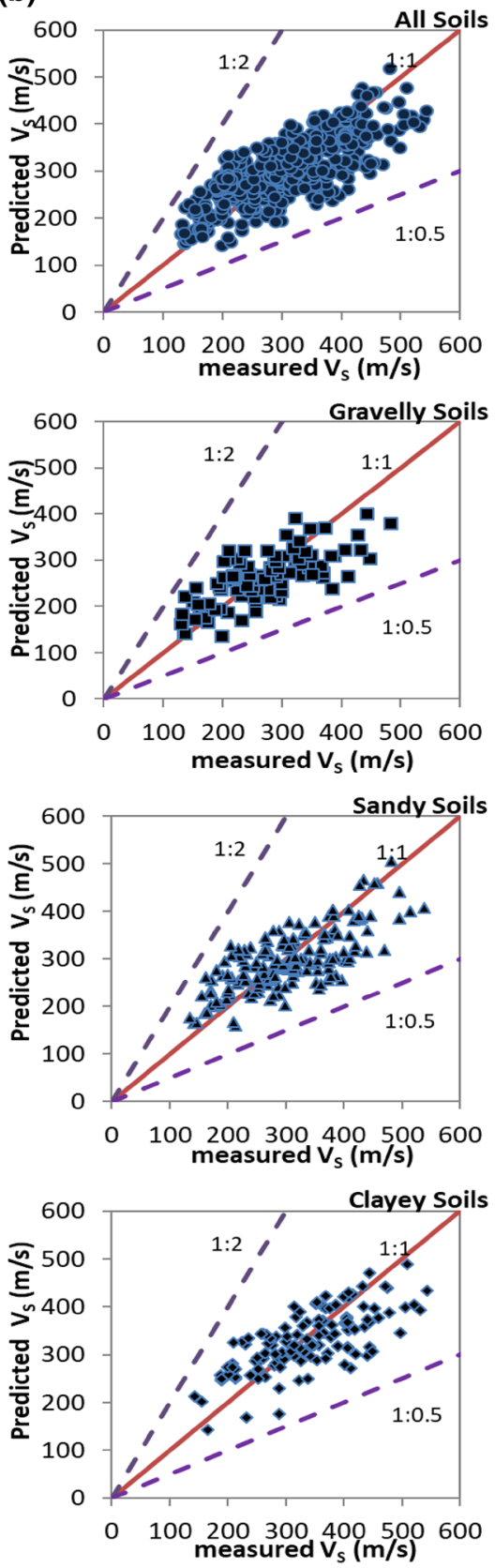

Figure 6. (a) Correlation between $V_{\mathrm{S}}$ and $\left(N_{1}\right)_{60}$ for all soil types, gravelly soils, sandy soils and clayey soils and (b) measured shear wave velocity vs. estimated shear wave velocity for four groups of soil.

models. In addition, in figure 7 (c) the residuals are scattered randomly that indicate constant variance of residuals and show the goodness of fit of regression models to data. The high correlation coefficients obtained in new equations show a high correlation between $V_{\mathrm{S}}$ and standard penetration resistance and that SPT is a determining factor for estimating $V_{\mathrm{S}}$. Histograms of standard residuals, normal probability plots of residuals and scatter plots were prepared for regression equations (16-19) and it was found that residuals were normal in these models and the error variance was stable.

Another method for determining the effectiveness of the proposed equations to predict $V_{\mathrm{S}}$ value is to calculate the normalised consistency ratio. This ratio is calculated as follows:

$$
C_{d}=\left(V_{\mathrm{SM}}-V_{\mathrm{SC}}\right) / N
$$

where $V_{\mathrm{SC}}$ is the shear wave velocity $(\mathrm{m} / \mathrm{s})$ calculated through equations $(9-12), V_{\mathrm{SM}}$ is the 

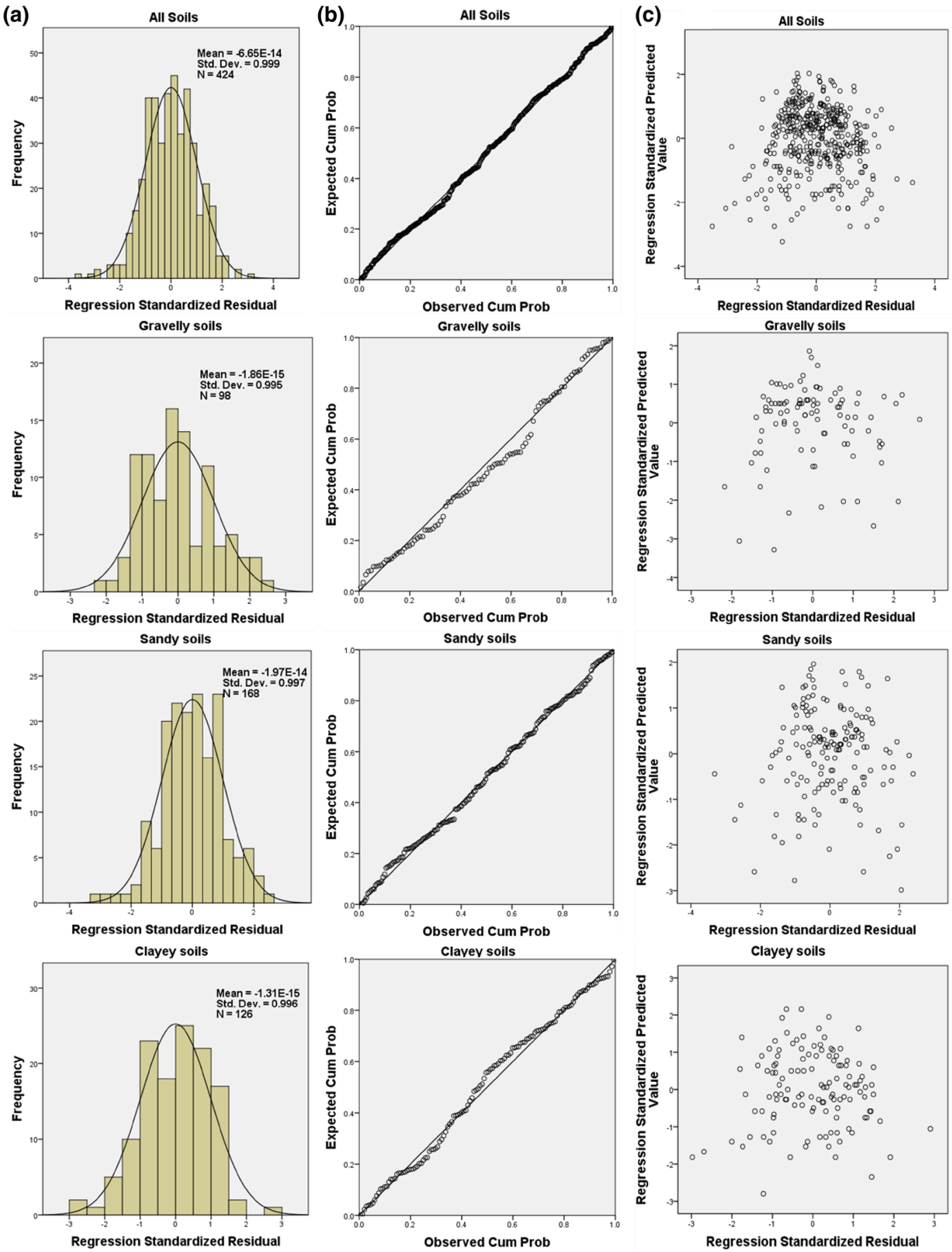

Figure 7. (a) Histogram of standard residuals with normal line, (b) normal probability of residuals ( $\mathrm{p}-\mathrm{p}$ plot) and (c) standard residuals vs. standard predicted values for the four groups of soil under study.

shear wave velocity measured in field through the downhole method and $N$ is the uncorrected standard penetration resistance of soil. Comparison between $V_{\mathrm{SM}}$ and $V_{\mathrm{SC}}$ values using the calculated $C_{d}$ ratio is shown in figure 8 . As shown in this figure, $C_{d}$ values for all four groups except the $N$ values less than 15 blows, tend to zero and this is indicative of the good performance of the proposed models in prediction of $V_{\mathrm{S}}$.
Normalised consistency ratio was also calculated for regression models prepared with corrected $V_{\mathrm{S}}$ and $\mathrm{SPT}-N$ value. In this case, this ratio is calculated as follows:

$$
C_{d}=V_{\mathrm{SM}(\text { corrected })}-V_{\mathrm{SC}(\text { corrected })} /\left(N_{1}\right)_{60},
$$

where $V_{\mathrm{SC} \text { (corrected) }}$ is the shear wave velocity $(\mathrm{m} / \mathrm{s})$ calculated through equations (16-19), $V_{\mathrm{SM}}$ (corrected) 

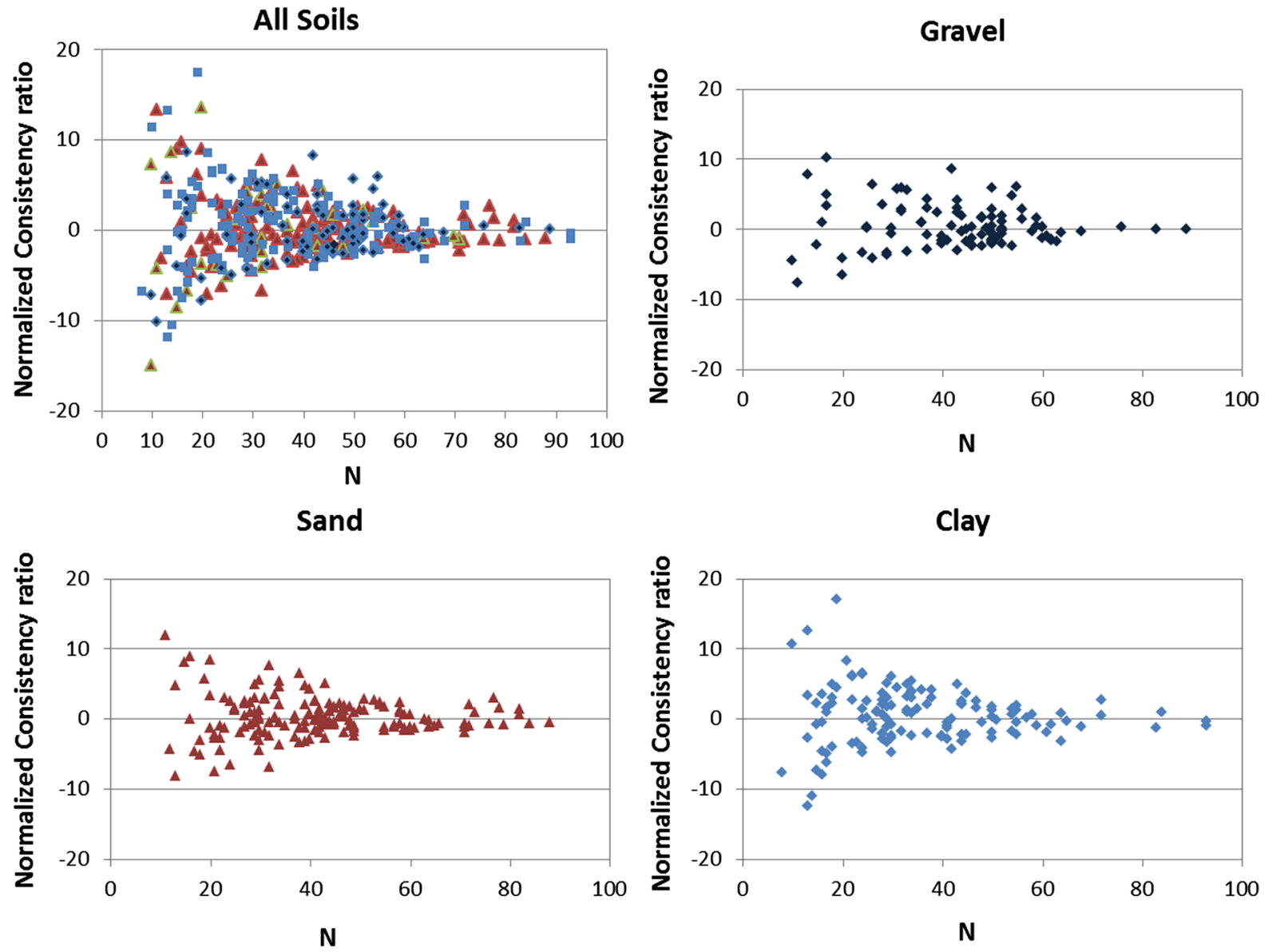

Figure 8. Normalised consistency ratio $\left(C_{d}\right)$ calculated using uncorrected $N$ value and $V_{\mathrm{S}}$, for all soil types, gravelly, sandy and clayey soil.

is the shear wave velocity measured in field through the downhole method and corrected for effective stress and $\left(N_{1}\right)_{60}$ is the corrected standard penetration resistance of soil.

The $C_{d}$ values obtained from each of the four soil types are depicted in figure 9. As shown in this figure, in each of the four soil types under study, the normalised residuals $\left(C_{d}\right)$ show more scattering than the uncorrected state and the error value is considerable even in the $N$ values of about 30 . Therefore, it can be concluded that with the correction of the SPT and $V_{\mathrm{S}}$ values, we will have regression equations with higher errors that do not have enough precision for predicting the value of $V_{\mathrm{S}}$.

\subsection{Variation in $V_{\mathrm{S}}$ with type of soil}

The effect of soil type on estimating $V_{\mathrm{S}}$ with both uncorrected and corrected SPT- $N$ values is shown in figure 10( $a$ and b). It is observed from uncorrected correlations in figure 10(a) that for a constant $\mathrm{SPT}-N$ value, the $V_{\mathrm{S}}$ value for all soil types, gravelly soil, sandy and clayey soil shows a slight variation and this is meant that soil type has no significant effects on these correlations. This finding is consistent with the findings of Sykora and Stokoe (1983), Sisman (1995), Iyisan (1996), Hasancebi and Ulusay (2007) and Dikmen (2009). With regard to this finding it is concluded that in areas with similar geological conditions there is no need to separate the $V_{\mathrm{S}}-N$ correlations based on soil type.

In the case of corrected $V_{\mathrm{S}}-N$, the value of $V_{\mathrm{S}}$ for all soil types and sandy and clayey soil shows small variation. However, for gravelly soil, the $V_{\mathrm{S}}$ value is high compared to other groups of soil especially for $n$ value larger than 20. This implies that type of soil influences values of $V_{\mathrm{S}}$ at a particular location in the case that corrected correlations are used. 

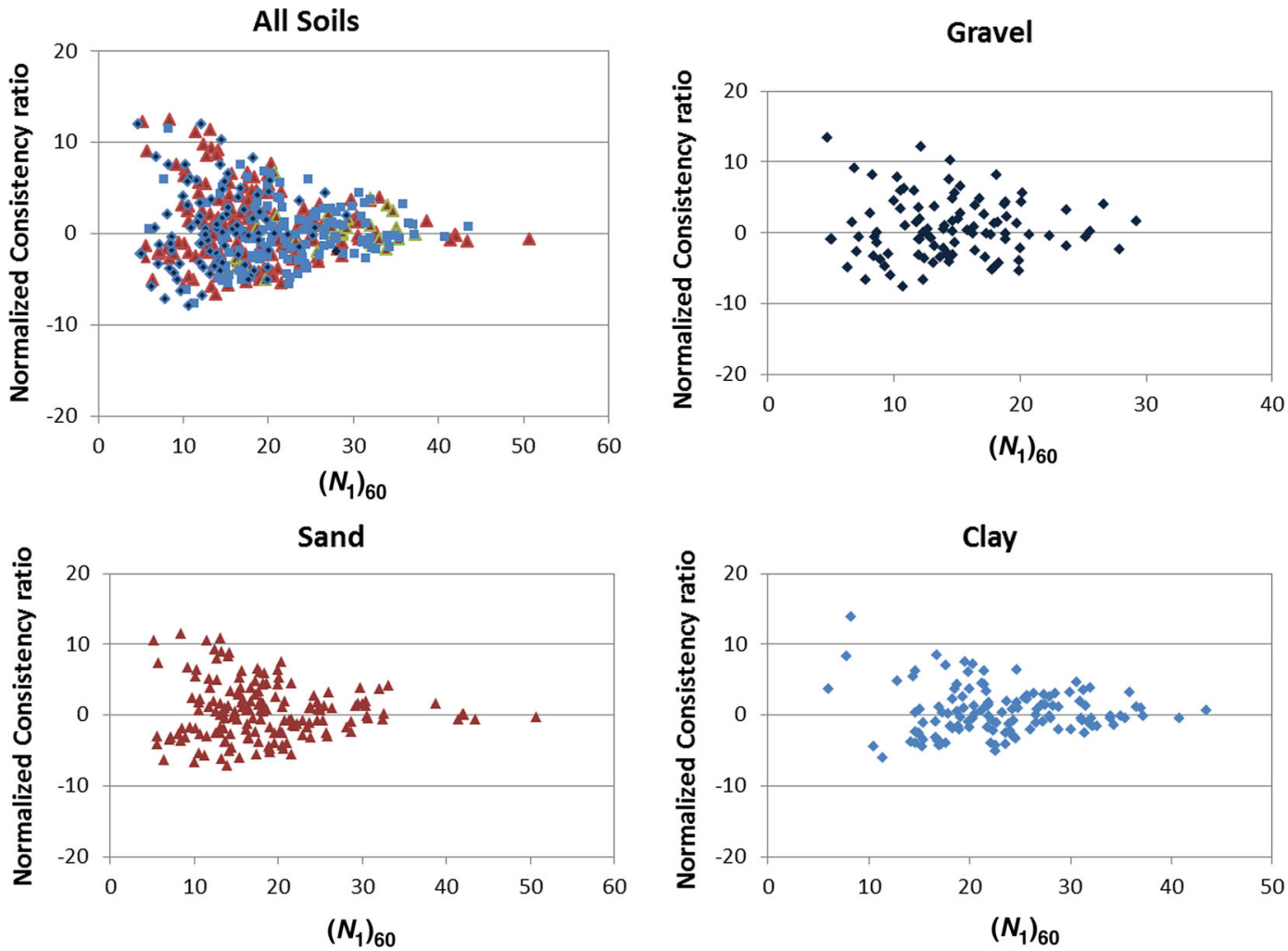

Figure 9. Normalised consistency ratio $\left(C_{d}\right)$ calculated using corrected $N$ value and $V_{\mathrm{S}}$, for all soil types, gravelly, sandy and clayey soil.

(a)

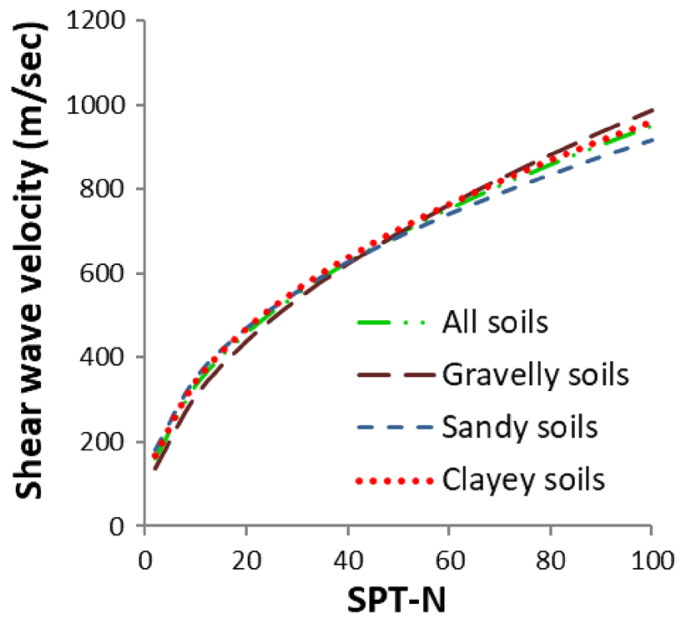

(b)

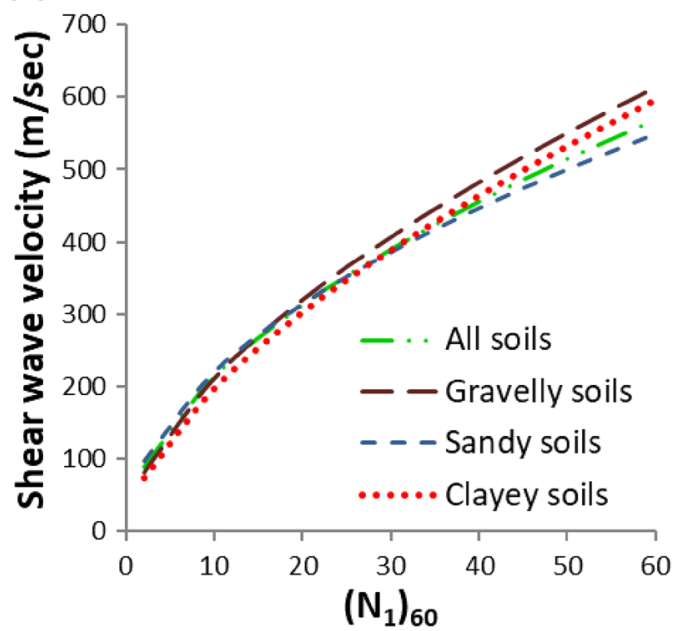

Figure 10. The effect of soil type on the relationships between (a) uncorrected SPT- $N$ and $V_{\mathrm{S}}$, and (b) corrected SPT- $N$ and $V_{\mathrm{S}}$.

\subsection{Comparison of the new equations with previous published correlations}

$V_{\mathrm{S}}$ calculated using equations (9)-(12) and a number of relationships published in the literature which are shown in table 1 are depicted in figure 11. Due to the large number of correlations and diagrams, in the plotted figures only the range of the relationships provided for each country has been determined. As shown in this figure, there are significant differences between new equations and the presented relationships for other countries. In figure 11(a) it is shown that the correlation proposed by Ohba and Toriuma (1970) for Japan 

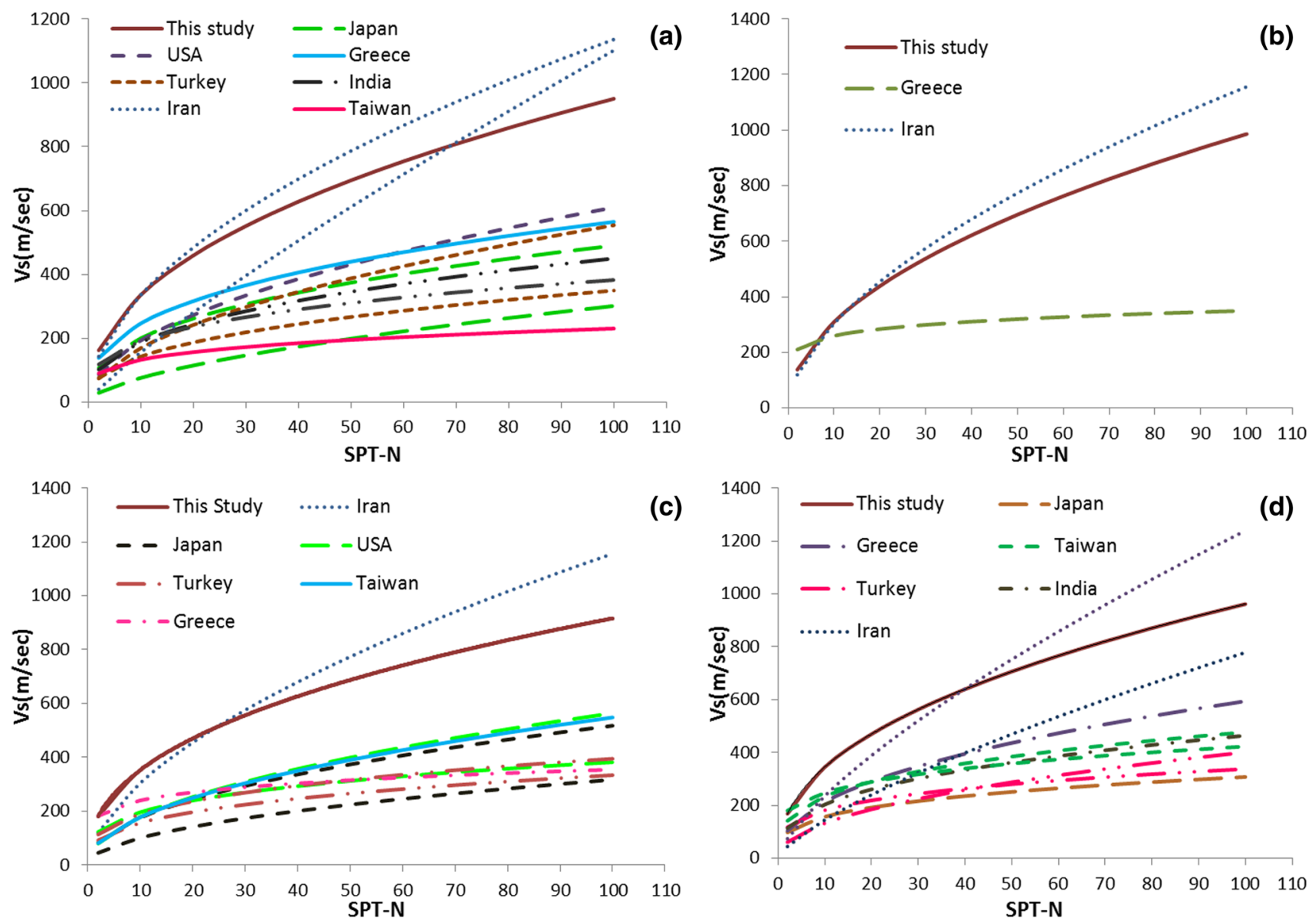

Figure 11. Comparison between previous published correlations and new equations for uncorrected SPT- $N$ value and $V_{\mathrm{S}}$ : (a) all soil types, (b) gravelly soil, (c) sandy soil and (d) clayey soil.

gives the least $V_{\mathrm{S}}$ for all the values of SPT when compared with other correlations. Compared with new equations in this study, equations suggested for Japan, India, USA, Greece, Turkey, Taiwan and Iran by researchers mentioned in table 1 estimate lower $V_{\mathrm{S}}$ values for all groups of soil for all $N$ values. However, almost all of correlations mentioned above show a similar trend to the new equation. The only relationship showing a different trend with all other equations as well as the new equation was provided by Jafari et al. (1997, 2002) for soil in Tehran.

The $V_{\mathrm{S}}$ obtained from correlations proposed for Iran is relatively comparable with new equation. The relationship presented by Hafezi Moghaddas et al. (2010) is in line well with new equation for $N$ value smaller than 15 and beyond which it gives slightly higher $V_{\mathrm{S}}$ values. The same differences can be found in related plots for gravelly soil, sandy soil and clayey soil; then a similar explanation also applies for figure $11(b-d)$.
$V_{\mathrm{S}}$ calculated by relationships (16)-(19) for corrected $V_{\mathrm{S}}-N$ as well as some of the correlations proposed in previous studies as mentioned in table 2 are depicted in figure 12. As shown in all soil groups in figure 11(a), compared with the uncorrected condition there is less difference between the predicted values in this study and the predicted values of other countries. However, the difference between the correlations is significant. In the case of gravelly soil, estimations by Rollins et al. (1998) in the USA up to $N$ value about 30 are comparable with values estimated by equation (17). However, this equation underestimates $V_{\mathrm{S}}$ in $N$ value more than 30 . In figure $12(\mathrm{c})$ only the correlation provided by Chatterjee and Choudhury (2013) for India is comparable with equation (18) in the present study, although compared to the current study the $V_{\mathrm{S}}$ values were underestimated.

The specific geotechnical conditions of the study area are probably the main reason for these major 

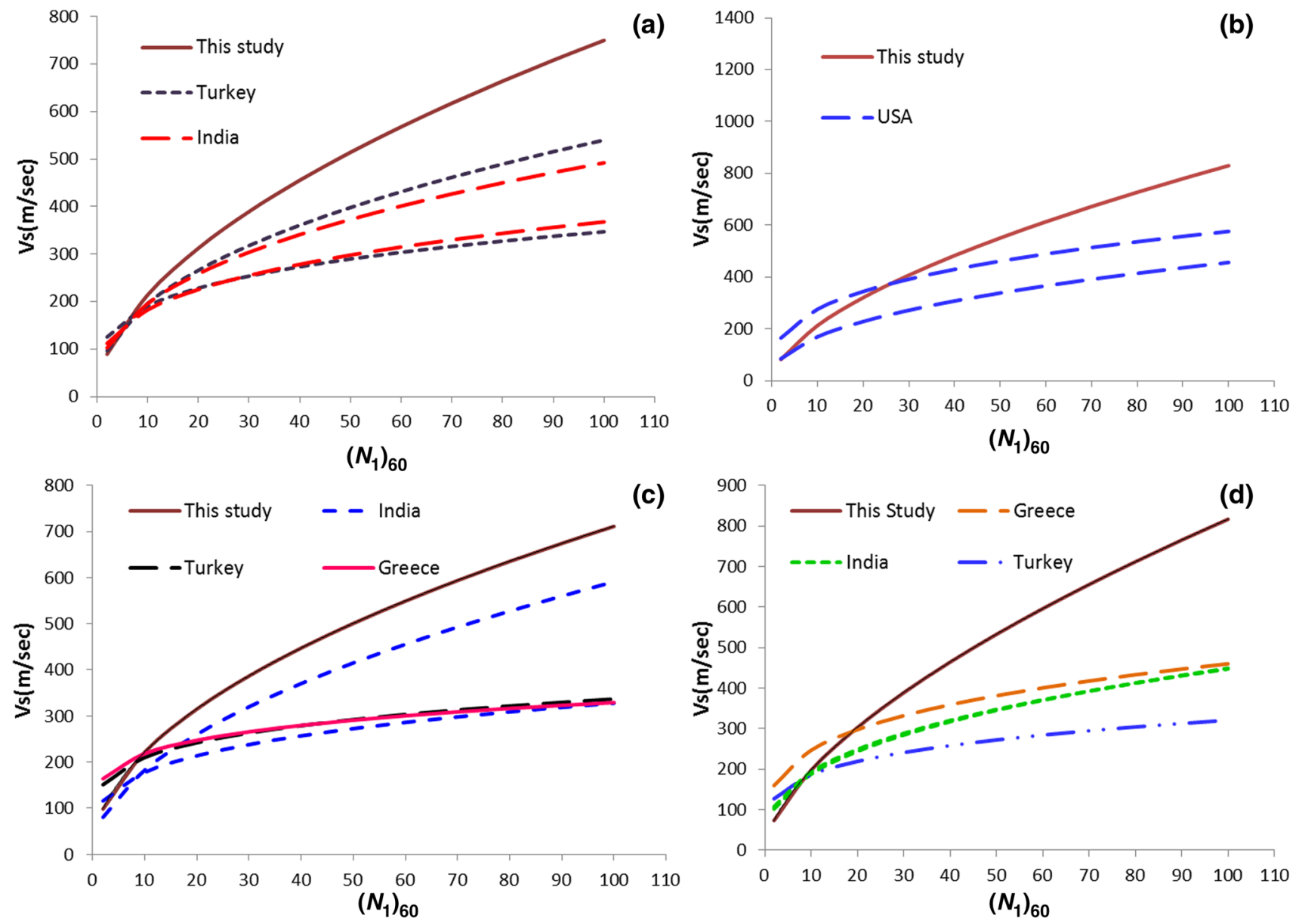

Figure 12. Comparison between previous published correlations and new equations for corrected SPT- $N$ value and $V_{\mathrm{S}}$ : (a) all soil types, (b) gravelly soil, (c) sandy soil and (d) clayey soil.

differences between new equations and previous correlations. In addition, other factors such as geological age, changes in groundwater level and over consolidation of soil may cause part of these differences. As was mentioned earlier, Mashhad is located in an area with dry climate and annual rainfall is low. The depth to groundwater level throughout the city is high and this can be one of the main reasons of increasing $V_{\mathrm{S}}$ value compared to other relationships. In addition, in the sediments of dry areas, the cementation issue can also play a significant role in raising soil resistance. In samples extracted from deposits in the study area, cementation was clearly observed.

Furthermore, various types of equipment used for SPT test and the various procedures for conducting this test have significant effects on the results obtained by this test. For example, the energy transmitted to the standard sampler is strongly affected by a number of variables including the type of hammer, anvil, lifting mechanism and the method of hammer release (Youd and Idriss 2001). Moreover, the borehole diameter, length and diameter of drilling rod, blow rate, and even the expertise of the operator would affect the SPT results. In Iran, automatic devices are less used and the SPT test is mostly conducted manually. In addition, we have no exact measurement of the amount of energy exerted on the hammer. All of these can also be the reasons for the inconsistent results of this study with the findings of other researchers.

On the other hand, the $V_{\mathrm{S}}$ used in the development of each previous relationship was measured by different methods. This also can be one of the reasons for the creation of differences in the relationships. Also, some of these relationships were developed for a specific range of SPT and $V_{\mathrm{S}}$ values and a few other relationships were developed by assuming the $N$ value less than 1 or by extrapolating $N$ value more than 100 or 50 to estimate the $V_{\mathrm{S}}$. But in this study, only measured 
SPT and $V_{\mathrm{S}}$ values were used for developing new equations. Therefore, with respect to all cases mentioned above, we should expect differences, minor or major, in the proposed relationships by different people in different areas. Future effort should be aimed at reducing the variability in these correlations by precise measurements of SPT and $V_{\mathrm{S}}$. The suggested equations are not an exact substitute for geophysical measurements and uncertainty in predictions should be considered when using these correlations.

\section{Conclusions}

In the current study, reliable geotechnical and geophysical data were collected from 88 boreholes across 84 locations in Mashhad city. As none of the published correlations fit these pieces of data well, it was attempted to develop new empirical relations between corrected and uncorrected SPT- $N$ value with $V_{\mathrm{S}}$ for all soil types of Mashhad city. Data were analysed using the linear, exponential, power, logarithmic and other mentioned models and the values of coefficient of determination $\left(R^{2}\right), R$, the SSE, SST, MSE, and root mean square error (RMSE) were calculated for each model. The high value of $R$ and $R^{2}$ and low value of errors for the power model showed that this model provides the best fit relation between the two parameters of $V_{\mathrm{S}}$ and SPT- $N$. Therefore, correlations between corrected and uncorrected $N$ and $V_{\mathrm{S}}$ were obtained for all soil types, sandy soil, and clayey soil using regression analysis (with power model). The high correlation coefficient for all derived correlations shows a strong correlation between these two characteristics of soil (SPT and $V_{\mathrm{S}}$ ) indicating an acceptable application of these proposed correlations for estimating the $V_{\mathrm{S}}$ value of this area.

By studying the effect of soil type on the estimated $V_{\mathrm{S}}$ value through the proposed equations, it was observed that in the case of correlations between corrected $N$ values and $V_{\mathrm{S}}$, the effect of soil type cannot be ignored. The site (Mashhad city) was classified based on measured shear wave velocity on top of $30 \mathrm{~m}$ depth of soil deposits $\left(V_{\mathrm{S} 30}\right)$ suggested by NEHRP guidelines. As per the NEHRP manual, most of the area comes under site class $\mathrm{C}$ and some locations are categorised as site class D. Therefore, most of the area can be classified as stiff to dense soil. The eastern areas of Mashhad show lower $V_{\mathrm{S}}$ than the western areas of this city. This low velocity can be related to the geological conditions and soil texture in this area.

The developed correlations were compared against the correlations proposed for Iran and other countries. It was observed that the shear wave velocity obtained from correlations proposed for Iran is relatively comparable with new equations. Although the proposed equations in this study follow a similar trend of curves as observed for other countries, there are significant differences between new equations and the presented relationships for other countries. This can be attributed to specific geotechnical conditions of the study area, geological age, changes in groundwater level, cementation and over consolidation of soil, procedures for conducting SPT, different methods for measuring $V_{\mathrm{S}}$ and other factors.

Therefore, the proposed uncorrected and corrected $V_{\mathrm{S}}-N$ correlations for various soil types of Mashhad city are practical techniques to determine shear wave velocity using measured SPT blow counts. The shear wave velocity calculated from the new equations can be utilised for seismic microsonation, ground response analysis and hazard assessment for Mashhad city. All the results obtained from the current study and previous studies reveal that empirical correlations derived from a local data set should not be used to approximate $V_{\mathrm{S}}$ directly from SPT- $N$ values for different sites. Therefore, these proposed correlations should be used with caution in geotechnical engineering and should be checked against the measured $V_{\mathrm{S}}$.

One of the limitations in this study is the low number of $V_{\mathrm{S}}$ data in the eastern part of Mashhad which might reduce the accuracy of provided equations in this part of the city. Therefore, future researchers are suggested to measure shear wave velocity of soil in this part of city to possibly have more exact equations. It is also suggested to have an exact measurement of the amount of energy exerted through hammers commonly used in Mashhad city so that SPT results can be used to estimate $V_{\mathrm{S}}$ values with more certainty.

\section{Acknowledgements}

The authors appreciate cooperation from consulting engineering companies and soil mechanics laboratories in Mashhad city for providing their geotechnical reporting for use in this paper. They also acknowledge the kind cooperation from 
the Zamin Physic Pouya consulting engineering company for giving permission to use measured shear wave velocity.

\section{References}

Akbari M, Ghafoori M, Hafezi Moghaddas N and Lashkaripour G L 2011 Seismic microzonation of Mashhad city, northeast Iran; Ann. Geophys.-Italy 54(4) 424-434; https://doi.org/10.4401/ag-4771.

Akin M K, Kramer S L and Topal T 2011 Empirical correlations of shear wave velocity $\left(V_{S}\right)$ and penetration resistance (SPT- $N$ value) for different soils in an earthquake-prone area (Erbaa-Turkey); Eng. Geol. 119 $1-17$.

Apostolidis P I, Raptakis D G, Pandi K K, Manakou M V and Pitilakis K D 2006 Definition of subsoil structure and preliminary ground response in Aigion city (Greece) using microtremor and earthquakes; Soil Dyn. Earthq. Eng. 26 922-940.

ASTM-D7400 2008 Standard test methods for downhole seismic testing; ASTM International, West Conshohocken, PA, USA.

ASTM-D1586 2011 Standard test method for standard penetration test (SPT) and split-barrel sampling of soils; ASTM International, West Conshohocken, PA, USA.

Athanasopoulos G A 1995 Empirical correlations $\mathrm{V}_{\text {So }}-\mathrm{NSPT}$ for soils of Greece: A comparative study of reliability; In: Proceedings of 7th international conference on soil dynamics and earthquake engineering, Computation Mechanics Publications, Southampton, Boston, pp. 19-25.

Azadi A, Javan-Doloei G H, Hafezi Moghadas N and Hessami-Azar K 2010 Geological, geotechnical and geophysical characteristics of the Toos Fault located North of Mashhad, North-eastern Iran; J. Exp. Soc. Psychol. 35(4) 17-34 (in Persian).

Baziar M H, Fallah H, Razeghi H R and Khorasani M M 1998 The relation of shear wave velocity and SPT for soils in Iran; In: Proceedings of the 11th European conference on earthquake engineering, Paris, France.

Berberian M and Ghoreshi M 1989 Seismic-fault hazard and project engineering of thermal power plant of Nishapur; Seismotectonical Survey, Ministry of Energy, Power Engineering Corporation report (Moshanir), Tehran (in Persian).

Borcherdt R D 1994 Estimates of site-dependent response spectra for design (methodology and justification); Earthq. Spectra. 10(4) 617-653.

Brown L T, Diehl J G and Nigbor R L 2000 A simplified procedure to measure average shear wave velocity to a depth of 30 meters $\left(\mathrm{V}_{\mathrm{S} 30}\right)$; In: 12th World conference on earthquake engineering, Auckland, New Zealand.

BSSC 2001 NEHRP recommended provisions for seismic regulations for new buildings and other structures (FEMA 368); Building Seismic Safety Council for the Federal Emergency Management Agency, Washington, DC, USA.

Chatterjee K and Choudhury D 2013 Variations in shear wave velocity and soil site class in Kolkata city using regression and sensitivity analysis; Nat. Hazards $692057-$ 2082 .
Dikmen U 2009 Statistical correlations of shear wave velocity and penetration resistance for soils; J. Geophys. Eng. 6 $61-72$.

Fabbrocino S, Lanzano G, Forte G, Santucci de Magistris F and Fabbroccini G 2015 SPT blow count vs. shear wave velocity relationship in the structurally complex formations of the Molise Region (Italy); Eng. Geol. 187 84-97.

Hafezi Moghaddas N, Azadi A and Amanian M 2010 Assessment of shear wave velocity based on standard penetration and accuracy of the results in the range of Mashhad City; In: Fourteenth Conference of Iran Geophysics, Geophysical Institute (in Persian).

Hardin B and Richart F 1963 Elastic wave velocities in granular soils; J. Soil Mech. Found. Div., ASCE 89(1) 33-65.

Hasancebi N and Ulusay R 2007 Empirical correlations between shear wave velocity and penetration resistance for ground shaking assessments; Bull. Eng. Geol. Environ. 66 203-213.

Holzer T L, Padovani A C, Bennett M J, Noce T E and Tinsely J C 2005 Mapping $V_{\mathrm{S} 30}$ site classes; Earthq. Spectra. $21335-370$.

Imai T 1977 P- and S-wave velocities of the ground in Japan; In: Proceedings of the IX, International Conference on Soil Mechanics and Foundation Engineering, pp. 127-132.

Imai T and Tonouchi K 1982 Correlation of $N$ value with $S$ wave velocity and shear modulus; In: Proc. 2nd European Symp. on Penetration Testing, Amsterdam, pp. 67-72.

Imai T and Yoshimura Y 1970 Elastic wave velocity and soil properties in soft soil; Tsuchito-Kiso 18(1) 17-22 (in Japanese).

Imai T and Yoshimura Y 1975 The relation of mechanical properties of soils to $\mathrm{P}$ and $\mathrm{S}$-wave velocities for ground in Japan; Technical Note, OYO Corporation.

Inazaki T 2006 Relationship between S-wave velocities and geotechnical properties of alluvial sediments; In: Proceedings of the 19th EEGS symposium on the application of geophysics to engineering and environmental problems 2006, pp. 1296-1303.

Iranian Code of Practice for Seismic Resistant Design of Building 2005; 3rd revision (Standard No. 2800), Building and Housing Research Center.

Iyisan R 1996 Correlations between shear wave velocity and in-situ penetration test results. Chamber of Civil Engineers of Turkey; Tek Dergi. 7(2) 1187-1199.

Jafari M K, Asghari A and Rahmani I 1997 Empirical correlation between shear wave velocity $\left(V_{S}\right)$ and SPT $N$ value for south of Tehran soils; In: Proc. 4th Int. Conf. Civil Engineering, Tehran, Iran.

Jafari M K, Shafiee A and Razm khah A 2002 Dynamic properties of fine grained soils in south of Tehran; Soil Dyn. Earthq. Eng. 4 25-35.

Jinan Z 1987 Correlation between seismic wave velocity and the number of blow of SPT and depth; Selected papers from the Chin. J. Geotech. Eng. ASCE, pp. 92-100.

Kanai K 1966 Observation of microtremors, XI: Matsushiro earthquake swarm areas, Bull. Earthq. Res. Inst., Vol. XLIV(3), University of Tokyo, Tokyo, Japan.

Kayen R E, Mitchell J K, Seed R B, Lodge A, Nishio S and Coutinho R 1992 Evaluation of SPT, CPT, and shear wave-based methods for liquefaction potential assessment using Loma Prieta data; In: Proceedings of the fourth 
Japan-US workshop on earthquake-resistant design of lifeline facilities and counter measures for soil liquefaction, NCEER-90-0019 (eds) Hamada I M and O'Rourke T D, National Center for Earthquake Engineering Research (NCEER), State Univ. of New York at Buffalo, NY, Vol. 1, pp. 177-204.

Kiku H, Yoshida N, Yasuda S, Irisawa T, Nakazawa H, Shimizu Y, Ansal A and Erkan A 2001 In-situ penetration tests and soil profiling in Adapazari, Turkey; In: Proceedings of the ICSMGE/TC4 satellite conference on lessons learned from recent strong earthquakes, pp. 259-265.

Kramer S L 1996 Geotechnical earthquake engineering; Prentice Hall Civil Engineering and Engineering Mechanics Series, Prentice Hall, Upper Saddle River, 653p.

Lang D H and Schwarz J 2006 Instrumental subsoil classification of Californian strong-motion sites based on single-station measurements; In: Eighth U.S. national conference on Earthquake Engineering, San Francisco, USA.

Lee S H H 1990 Regression models of shear wave velocities; J. Chin. Inst. Eng. 13 519-532.

Lee S H H 1992 Analysis of the multicollinearity of regression equations of shear wave velocities; Soils Found. 32(1) 205214.

Liao S S C and Whitman R V 1986 Catalogue of liquefaction and non-liquefaction occurrences during earthquakes; Research Rep. Prepared for Dept. of Civil Eng., Massachusetts Institute of Technology, Cambridge, MA.

Maheshwari R U, Boominathan A and Dodagoudar G R 2010 Use of surface waves in statistical correlations of shear wave velocity and penetration resistance of Chennai soils; Geotech. Geol. Eng. 28 119-137.

Martin A J and Diehl J G 2004 Practical experience using a simplified procedure to measure average shear-wave velocity to a depth of 30 meters $\left(V_{\mathrm{S} 30}\right)$; In: 13th World conference on earthquake engineering, Vancouver, B.C., Canada.

Mhaske S Y and Choudhury D 2011 Geospatial contour mapping of shear wave velocity for Mumbai city; Nat. Hazards 59 317-327.

Ohba S and Toriuma I 1970 Research on vibrational characteristics of soil deposits in Osaka. Part 2: On velocities of wave propagation and predominant periods of soil deposits. Abstracts of Technical Meeting of Architectural Institute of Japan.

Ohsaki Y and Iwasaki R 1973 On dynamic shear moduli and Poisson's ratio of soil deposits; Soils Found. 13(4) 61-73.

Ohta Y and Goto N 1978 Empirical shear wave velocity equations in terms of characteristics soil indexes; Earthq. Eng. Struct. Dyn. 6 167-187.

Ohta T, Hara A, Niwa M and Sakano T 1972 Elastic moduli of soil deposits estimated by $N$-values; In: Proc. 7th annual conference, The Japanese Society of Soil Mechanics and Foundation Engineering, pp. 265-268.

Pitilakis K D, Anastasiadis A and Raptakis D 1992 Field and laboratory determination of dynamic properties of natural soil deposits; In: Proceedings of the 10th world conference on earthquake engineering, Rotherdam, pp. 1275-1280.

Pitilakis K, Raptakis D, Lontzetidis K, Tika-Vassilikou T and Jongmans D 1999 Geotechnical and geophysical description of Euro-Seistests, using field, and laboratory tests and moderate strong ground motions; J. Earthq. Eng. 3(3) 381-409.
Rahimi E, Nikoudel M R, Hafezi Moghaddas $\mathrm{N}$ and Ghayamghamian M R 2012 Evaluating local geological conditions and $V_{S}$ profiles in Khash area, SE Iran; Science Series Data Report, Vol 4, No. 12.

Raptakis D G, Anastasiadis S A J, Pitilakis K D and Lontzetidis K S 1995 Shear wave velocities and damping of Greek natural soils; In: Proc. 10th European Conf. Earthquake Engg., Vienna, pp. 477-482.

Robertson P K and Wride C E 1998 Evaluating cyclic liquefaction potential using the cone penetration test; Can. Geotech. J. Ottawa 35(3) 442-459.

Rollins K M, Evans M D, Diehl N B and Daily W D 1998 Shear modulus and damping relationships for gravels; $J$. Geotech. Geoenviron. Eng. 124(5) 396-405.

Seed H B and Idriss I M 1981 Evaluation of liquefaction potential sand deposits based on observation of performance in previous earthquakes; In: Preprint 81544, in-situ testing to evaluate liquefaction susceptibility, ASCE National Convention, Missouri, pp. 81-544.

Seed H B and Idriss I M 1982 Ground motions and soil liquefaction during earthquakes, Monograph, No. 5; Earthquake Engineering Research Institute, University of California, Berkeley.

Seed H B, Idriss I M and Arango I 1983 Evaluation of liquefaction potential using field performance data; J. Geotech. Eng. 109(3) 458-482.

Sherif Aggour M and Rose Radding W 2001 Standard penetration test (SPT) correction, research report, Maryland state highway administration, office of policy and research; Report No. MD02-007B48.

Shibata T 1970 The Relationship between the N-Value and S-Wave Velocity in the Soil Layer; Disaster Prevention Research Laboratory, Kyoto University, Kyoto, Japan.

Sil A and Sitharam T G 2013 Dynamic site characterization and correlation of shear wave velocity with standard penetration test ' $\mathrm{N}$ ' values for the city of Agartala, Tripura state, India; Pure Appl. Geophys. 171(8), https://doi.org/ 10.1007/s00024-013-0754-y.

Sisman H 1995 An Investigation on Relationships between Shear Wave Velocity, and SPT and Pressuremeter Test Results, Master of Science Thesis, Ankara University, Turkey.

Sitharam T G and Anbazhagan P 2007 Seismic hazard analysis for the Bangalore region; Nat. Hazards $40261-$ 278.

Sitharam T G and Anbazhagan P 2008 Seismic Microzonation: Principles, Practices and Experiments, EJGE Special Volume Bouquet 08, http://www.ejge.com/ Bouquet08/Preface.htm, P-61.

Skempton A K 1986 Standard penetration test procedures and the effects in sands of overburden pressure, relative density, particle size, aging, and overconsolidation; Geotechnique 36(3) 425-447.

Sykora D E and Stokoe K H 1983 Correlations of in-situ measurements in sands of shear wave velocity; Soil Dyn. Earthq. Eng. 20 125-36.

Ulugergerli E U and Uyanik O 2007 Statistical correlations between seismic wave velocities and SPT blow counts and the relative density of soils; J. Test Eval. 35(2) 1-5.

Williams R A, Wood S, Stephenson W J, Odum J K, Mere Monte M E, Street R and Worley D 2003 Surface 
seismic refraction/reflection measurement determinations of potential site resonances and the areal uniformity of NEHRP site class D in Memphis, Tennessee; Earthq. Spectra 19 159-189.
Youd T L and Idriss I M 2001 Liquefaction resistance of soils: Summary report from the 1996 NCEER and 1998 NCEER/NSF workshops on evaluation of liquefaction resistance of soils; J. Geotech. Geoenviron. 127(4).

Corresponding editor: N V CHALAPATHI RAO 